Prepared in cooperation with the U.S. Department of the Army Environmental and Natural Resources Management Office of the U.S. Army Signal Center and Fort Gordon

\title{
Assessment of Soil-Gas Contamination at Three Former Fuel-Dispensing Sites, Fort Gordon, Georgia, 2010-2011
}

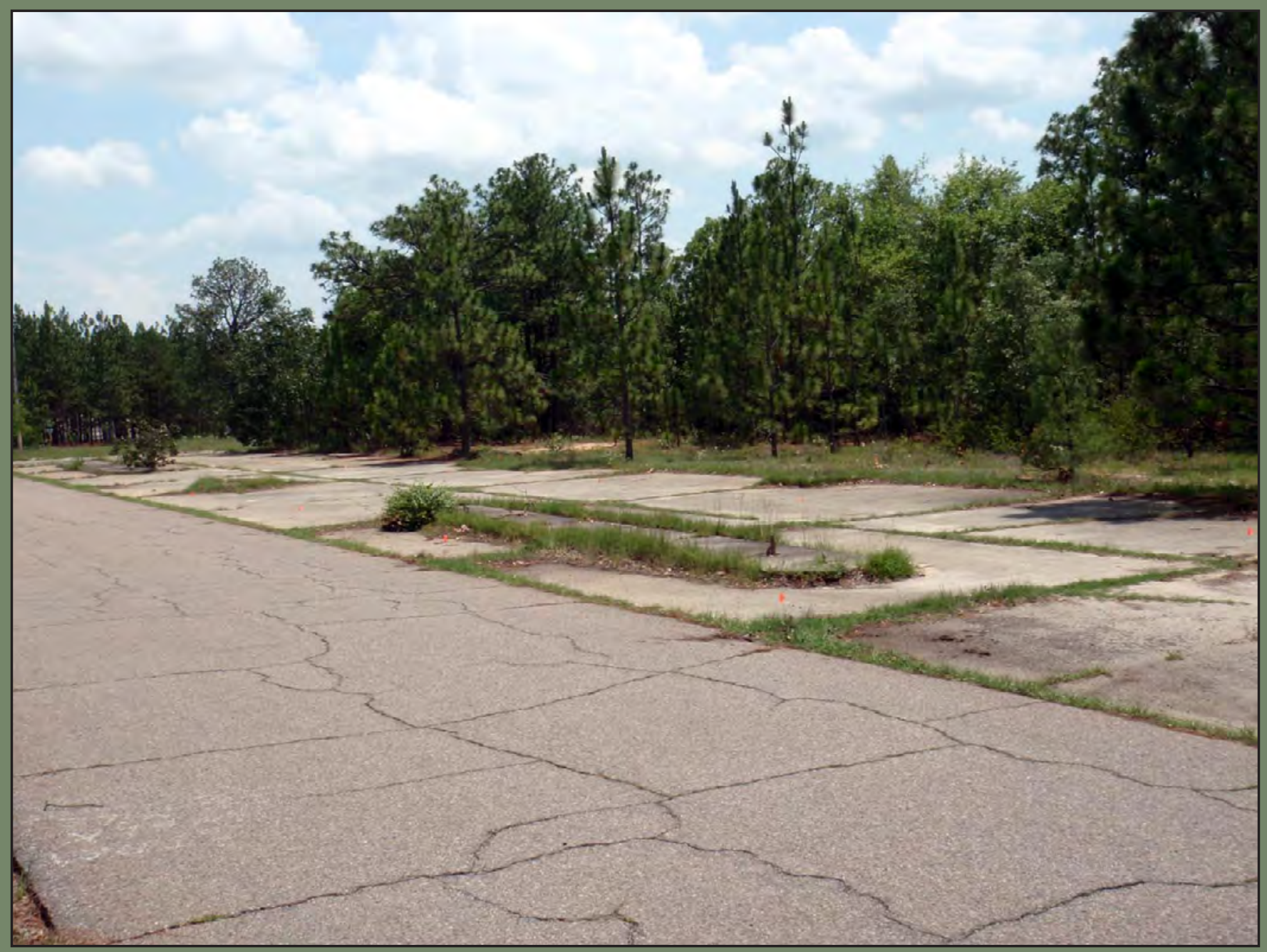

Open-File Report 2012-1082

U.S. Department of the Interior

U.S. Geological Survey 
Cover photograph. Former fuel-dispensing site at 8th Street, Fort Gordon, Georgia 


\section{Assessment of Soil-Gas Contamination at Three Former Fuel-Dispensing Sites, Fort Gordon, Georgia, 2010-2011}

By Andral W. Caldwell, W. Fred Falls, Wladmir B. Guimaraes, W. Hagan Ratliff, John B. Wellborn, and James E. Landmeyer

Prepared in cooperation with the U.S. Department of the Army Environmental and Natural Resources Management Office of the U.S. Army Signal Center and Fort Gordon

Open-File Report 2012-1082 


\title{
U.S. Department of the Interior \\ KEN SALAZAR, Secretary \\ U.S. Geological Survey \\ Marcia K. McNutt, Director
}

\author{
U.S. Geological Survey, Reston, Virginia: 2012
}

For more information on the USGS - the Federal source for science about the Earth, its natural and living resources, natural hazards, and the environment, visit http://Www.usgs.gov or call 1-888-ASK-USGS.

For an overview of USGS information products, including maps, imagery, and publications, visit $h t t p: / / w w w . u s g s . g o v / p u b p r o d$

To order this and other USGS information products, visit http://store.usgs.gov

Any use of trade, product, or firm names is for descriptive purposes only and does not imply endorsement by the U.S. Government.

Although this report is in the public domain, permission must be secured from the individual copyright owners to reproduce any copyrighted materials contained within this report.

Suggested citation:

Caldwell, A.W., Falls, W.F., Guimaraes, W.B., Ratliff, W.H., Wellborn, J.B., and Landmeyer, J.E., 2012, Assessment of soil-gas contamination at three former fuel-dispensing sites, Fort Gordon, Georgia, 2010-2011:

U.S. Geological Survey Open-File Report 2012-1082, 37 p. 


\section{Contents}

Abstract
Introduction
Purpose and Scope
Description of the Study Area
Methodss
Passive Soil-Gas Survey
8th Street Site
12th Street Site
12th Street Site

\section{Figures}

1. Locations of the 8th Street, Chamberlain Avenue, and 12th Street former fuel-dispensing sites, Fort Gordon, Georgia.

2. Photographs of soil-gas sampler prior to being installed in a shallow borehole and following retrieval from a borehole and prior to shipping to laboratory for analysis

3. Photograph of rotary hammer drill with stainless-steel drill bit used to drill boreholes for installation of the passive soil-gas samplers at the 8th Street, Chamberlain Avenue, and 12th Street sites.

4-19. Maps showing-

4. Locations of soil-gas samplers, 8th Street site, Fort Gordon, Georgia, June 29-August 12, 2011

5. Locations of soil-gas samplers, Chamberlain Avenue site, Fort Gordon, Georgia, July 7-12, 2011

6. Locations of soil-gas samplers, 12th Street site, Fort Gordon, Georgia, July $18-22,2011$

7. Detections of total petroleum hydrocarbons mass in soil-gas samplers, 8th Street site, Fort Gordon, Georgia, June 29-August 12, 2011

8. Detections of benzene mass in soil-gas samplers, 8th Street site, Fort Gordon, Georgia, June 29-August 12, 2011

9. Detections of toluene mass in soil-gas samplers, 8th Street site, Fort Gordon, Georgia, June 29-August 12, 2011

10. Detections of pentadecane mass in soil-gas samplers, 8th Street site, Fort Gordon, Georgia, June 29-August 12, 2011 
11. Detections of chloroform mass in soil-gas samplers, 8th Street site, Fort Gordon, Georgia, June 29-August 12, 2011

12. Detections of total petroleum hydrocarbons mass in soil-gas samplers, Chamberlain Avenue site, Fort Gordon, Georgia, July 7-12, 2011.

13. Detections of combined mass of benzene, toluene, ethylbenzene, and xylenes in soil-gas samplers, Chamberlain Avenue site, Fort Gordon, Georgia, July 7-12, 2011.

14. Detections of combined mass of undecane, tridecane, and pentadecane $\left(\mathrm{C}_{11}, \mathrm{C}_{13^{\prime}}\right.$ and $\mathrm{C}_{15}$ diesel compounds) in soil-gas samplers, Chamberlain Avenue site, Fort Gordon, Georgia, July 7-12, 2011

15. Detections of trimethylbenzenes mass in soil-gas samplers, Chamberlain Avenue site, Fort Gordon, Georgia, July 7-12, 2011.

16. Detections of tetrachloroethylene mass in soil-gas samplers, Chamberlain Avenue site, Fort Gordon, Georgia, July 7-12, 2011

17. Detections of total petroleum hydrocarbons mass in soil-gas samplers, 12th Street site, Fort Gordon, Georgia, July 18-22, 2011

18. Detections of toluene mass in soil-gas samplers, 12th Street site, Fort Gordon, Georgia, July 18-22, 2011

19. Detections of combined mass of undecane, tridecane, and pentadecane $\left(\mathrm{C}_{11}, \mathrm{C}_{13}\right.$, and $\mathrm{C}_{15}$ diesel compounds) in soil-gas samplers, 12th Street site, Fort Gordon, Georgia, July 18-22, 2011

\section{Tables}

1. Mass of volatile organic compounds detected in soil-gas samplers, deployed on June 29, 2011, collected from the 8th Street site, Fort Gordon, Georgia

2. Mass of volatile organic compounds detected in soil-gas samplers, deployed on August 8, 2011, collected from the 8th Street site, Fort Gordon, Georgia

3. Mass of volatile organic compounds detected in soil-gas samplers, deployed on July 7, 2011, collected from the Chamberlain Avenue site, Fort Gordon, Georgia

4. Mass of volatile organic compounds detected in soil-gas samplers, deployed on July 18, 2011, collected from the 12th Street site, Fort Gordon, Georgia 


\section{Conversion Factors}

\begin{tabular}{lcl}
$\begin{array}{c}\text { Inch/Pound to SI } \\
\text { Multiply }\end{array}$ & By & \multicolumn{1}{c}{ To obtain } \\
\hline \multicolumn{3}{c}{ Length } \\
\hline inch (in.) & 2.54 & centimeter $(\mathrm{cm})$ \\
inch (in.) & 25.4 & millimeter $(\mathrm{mm})$ \\
foot (ft) & 0.3048 & meter $(\mathrm{m})$ \\
mile (mi) & 1.609 & kilometer $(\mathrm{km})$ \\
\hline & & Area \\
\hline acre & 4,047 & \\
acre & 0.4047 & square meter $\left(\mathrm{m}^{2}\right)$ \\
acre & 0.4047 & hectare $(\mathrm{ha})$ \\
acre & 0.004047 & square hectometer $\left(\mathrm{hm}^{2}\right)$ \\
\hline
\end{tabular}

\section{Acronyms}

$\begin{array}{ll}\text { BTEX } & \text { Benzene, toluene, ethylbenzene, and xylene (total) } \\ \mathrm{C}_{11^{\prime}} \mathrm{C}_{13^{\prime}} \mathrm{C}_{15} & \text { Undecane, tridecane, and pentadecane (total) } \\ \mu \mathrm{g} & \text { microgram } \\ \text { MDL } & \text { Method detection level } \\ \text { MTBE } & \text { Methyl tert-butyl ether } \\ \mathrm{mL} & \text { milliliter } \\ \text { PAH } & \text { Polycyclic aromatic hydrocarbon } \\ \text { PCE } & \text { Perchloroethylene (also known as tetrachloroethylene) } \\ \text { RCRA } & \text { Resource Conservation and Recovery Act } \\ \text { RSL } & \text { Regional screening level } \\ \text { SVOC } & \text { Semivolatile organic compound } \\ \text { TMBs } & \text { combined masses of 1,3,5-trimethylbenzene and 1,2,4-trimethylbenzene } \\ \text { TCE } & \text { Trichloroethylene } \\ \text { TPH } & \text { Total petroleum hydrocarbon } \\ \text { USEPA } & \text { U.S. Environmental Protection Agency } \\ \text { USGS } & \text { U.S. Geological Survey } \\ \text { VOC } & \text { Volatile organic compound } \\ \text { 1,4-DCB } & \text { 1,4-dichlorobenzene }\end{array}$




\title{
Assessment of Soil-Gas Contamination at Three Former Fuel-Dispensing Sites, Fort Gordon, Georgia, 2010-2011
}

\author{
By Andral W. Caldwell, ${ }^{1}$ W. Fred Falls, ${ }^{1}$ Wladmir B. Guimaraes, ${ }^{1}$ W. Hagan Ratliff, ${ }^{2}$ John B. Wellborn, ${ }^{3}$ and \\ James E. Landmeyer ${ }^{1}$
}

\section{Abstract}

Soil gas was assessed for contaminants at three former fuel-dispensing sites at Fort Gordon, Georgia, from October 2010 to September 2011. The assessment included delineation of organic contaminants using soil-gas samplers collected from the former fuel-dispensing sites at 8th Street, Chamberlain Avenue, and 12th Street. This assessment was conducted to provide environmental contamination data to Fort Gordon personnel pursuant to requirements for the Resource Conservation and Recovery Act Part B Hazardous Waste Permit process.

Soil-gas samplers installed and retrieved during June and August 2011 at the 8th Street site had detections above the method detection level (MDL) for the mass of total petroleum hydrocarbons (TPH), benzene, toluene, ortho-xylene, undecane, tridecane, pentadecane, and chloroform. Total petroleum hydrocarbons soil-gas mass exceeded the MDL of 0.02 microgram in 54 of the 55 soil-gas samplers. The highest detection of TPH soil-gas mass was 146.10 micrograms, located in the central part of the site. Benzene mass exceeded the MDL of 0.01 microgram in 23 soil-gas samplers, whereas toluene was detected in only 10 soil-gas samplers. Ortho-xylene was detected above the MDL in only one soilgas sampler. The highest soil-gas mass detected for undecane, tridecane, and pentadecane was located in the northeastern corner of the 8th Street site. Chloroform mass greater than the MDL of 0.01 microgram was detected in less than one-third of the soil-gas samplers.

Soil-gas masses above the MDL were identified for $\mathrm{TPH}$, gasoline-related compounds, diesel-range alkanes, trimethylbenzenes, naphthalene, 2-methyl-napthalene, octane, and tetrachloroethylene for the July 2011 soil-gas

\footnotetext{
${ }^{1}$ U.S. Geological Survey.
}

${ }^{2}$ Environmental Branch, Fort Gordon, Georgia.

${ }^{3}$ Environmental and Natural Resources, Fort Gordon, Georgia. survey at the Chamberlain Avenue site. All 30 of the soil-gas samplers contained TPH mass above the MDL. The highest detection of TPH mass, 426.36 micrograms, was for a soil-gas sampler located near the northern boundary of the site. Gasoline-related compounds and diesel-range alkanes were detected in multiple soil-gas samplers, and the highest detections of these compounds were located near the central part of the site near existing, nonoperational, fuel-dispensing pumps. Trimethylbenzenes were detected in less than half of the soil-gas samplers. Naphthalene soil-gas mass was detected above the MDL in 10 soil-gas samplers, whereas 2-methyl-napthalene was detected above the MDL in half of the soil-gas samplers. Octane mass was detected above the MDL in one soil-gas sampler located near the central part of the site. Tetrachloroethylene soil-gas mass was detected above the MDL in more than half of the soil-gas samplers, and the highest tetrachloroethylene soil-gas mass of 0.90 microgram was located in the northeastern part of the site.

Soil-gas samplers collected at the 12th Street site during July 2011 contained soil-gas mass above the MDL for TPH, toluene, undecane, tridecane, and pentadecane (diesel-range alkanes), trichloroethylene, 1,4-dichlorobenzene, chloroform, and 1,2,4-trimethylbenzene. The highest detected TPH mass was 24.37 micrograms in a soil-gas sampler located in the northern part of the site. The highest detection of toluene soil-gas mass was from a soil-gas sampler located near the southern boundary of the site. The diesel-range alkanes were detected above the MDL in five soil-gas samplers; the highest detection of soil-gas diesel mass, 0.65 microgram, was located in the southern part of the site. Trichloroethylene and 1,4-dichlorobenzene were detected above the MDL in the northern part of the site in one soil-gas sampler that also had one of the highest detections of TPH. Chloroform was detected above the MDL in three soil-gas samplers, whereas 1,2,4-trimethylbenzene soil-gas mass was detected above the MDL in two soil-gas samplers. 


\section{Introduction}

Fort Gordon is a U.S. Department of the Army (U.S. Army) facility located approximately 10 miles southwest of Augusta in east-central Georgia (fig. 1). A cantonment (military housing) area is located at the northeastern boundary of Fort Gordon. The former fuel-dispensing sites for this investigation are at 8th Street, Chamberlain Avenue, and 12th Street (fig 1). The former fuel-dispensing sites are all located on a relatively flat and open area in the northeastern part of Fort Gordon and southwest of the cantonment area. Historically, little information is available about the past installation, operation, and decommissioning of these former fuel-dispensing sites other than the 8th Street and 12th Street sites were active from the 1940s to the 1970s and the Chamberlain Avenue site was opened in the 1960s (Hagan Ratliff, Environmental Branch, Fort Gordon, Georgia, oral commun., 2010).

Because of the lack of historical information regarding past operations at these sites, the effects of past activities on environmental resources at the 8th Street, Chamberlain Avenue, and 12th Street sites currently are unknown. The current assessment was conducted to provide environmental contamination data to Fort Gordon personnel to comply with the requirements of the Resource Conservation and Recovery Act (RCRA) Part B Hazardous Waste Permit process. An initial investigation to assess potential environmental effects is warranted because these areas are located in the outcrop area of the Dublin and Midville aquifer systems, which are used for drinking water by the towns of Augusta and Hephzibah (Williams, 2007). Moreover, groundwater flowing from these areas may discharge to streams in the area and potentially enable contaminants to be transported off of the Fort Gordon property.

\section{Purpose and Scope}

From October 2010 to September 2011, the U.S. Geological Survey (USGS), in cooperation with the U.S. Army Environmental and Natural Resources Management Office of the U.S. Army Signal Center and Fort Gordon, Georgia, assessed subsurface contamination at three former fuel-dispensing sites. This assessment was conducted to provide environmental contamination data to the U.S. Army at Fort Gordon. The assessment included the delineation of organic contaminants by using soil-gas samplers installed at the 8th Street, Chamberlain Avenue, and 12th Street sites. This report presents the analytical results of the soil-gas samplers and delineates those areas where contaminant mass exceeded the MDL for the organic compound of concern.

\section{Description of the Study Area}

Fort Gordon is a U.S. Army facility located approximately 10 miles southwest of Augusta in east-central Georgia (fig. 1). Fort Gordon is located in the northern part of the Coastal Plain Physiographic Province and south of the Fall Line. Fort Gordon is underlain by Cretaceous and Tertiary strata and is characterized by surficial soils and sediments of unconsolidated sands, indurated sands, and semiconsolidated sandstones, and layers of clay that include kaolinite (Gregory and others, 2001; Williams, 2007).

The study sites are former fuel-dispensing stations located at 8th Street, Chamberlain Avenue, and 12th Street (fig. 1). The 8th Street site is located in a flat, sparsely wooded area at the corner of 3rd Avenue and 12th Street, and across the street from former building 51101. The 8th Street site contains a concrete pad and raised concrete islands where the fuel pumps were once located. The Chamberlain Avenue site is located in a flat, open area with a concrete pad and raised concrete islands where the nonoperational pumps are still located, covering the entire site. The site is located on property currently (2012) leased by the Georgia National Guard between 8th Avenue and Chamberlain Avenue. The 12th Street site is located in a flat, open area with a concrete pad and raised concrete islands where the pumps were once located. The 12th Street site is located across the street from the 67th Expeditionary Signal Battalion Motor Pool.

\section{Methods}

The methods used in the assessment of soil gas were selected to provide data to determine the presence or absence of contaminants at the former fuel-dispensing sites at 8th Street, Chamberlain Avenue, and 12th Street. The soil-gas method that was used provides results that are qualitative and has been used effectively at other sites on the Fort Gordon property to identify areas of contamination (Caldwell and others, 2011; Falls and others, 2011).

\section{Passive Soil-Gas Survey}

The assessment of soil-gas contamination was conducted using a passive soil-gas survey based on the GORE ${ }^{\circledR}$ Module, a commercially available passive diffusion sampler based on GORE-TEX $^{\circledR}$ membrane technology (U.S. Environmental Protection Agency, 1998; W.L. Gore \& Associates, Inc., 2004; American Society for Testing and Materials, 2006). The module is an adsorbent material placed inside a shoestring-shaped GORE-TEX ${ }^{\circledR}$ tube (fig. $2 A$ ), which is contained in a 20 -milliliter $(\mathrm{mL})$ gas-tight vial (fig. $2 B$ ) sent by the commercial laboratory (W.L. Gore \& Associates, Inc.). The material can adsorb a wide variety of volatile organic compounds (VOCs), including solvents such as perchloroethylene (PCE; also known as tetrachloroethylene); trichloroethylene (TCE); benzene, toluene, ethylbenzene, and xylene (gasoline-range compounds; collectively referred to as BTEX); methyl tert-butyl ether (MTBE); semivolatile organic compounds (SVOCs); total petroleum hydrocarbons 
(TPH); and polycyclic aromatic hydrocarbons (PAHs) such as naphthalene. The modules were tied to a string, attached to a cork plug to prevent the entrance of surface water and ambient surface sources of contamination, and inserted into a shallow borehole. The borehole was 1.0-inch (in.) in diameter and approximately 18 - to 24-in. deep, and was created by a stainless-steel ship-auger bit, with a carbide tip, attached to an electric rotary hammer drill (fig. 3). The depth of each borehole was drilled within the range specified by the U.S. Environmental Protection Agency (USEPA) for soil-gas investigations (U.S. Environmental Protection Agency, 1998). The hammer drill was needed in order to drill through a 6- to 10-in.-thick concrete pad at the sites. The auger was cleaned with a paper towel between each borehole drilling. After 4 to 6 days, the modules were removed from the field, placed in their original $20-\mathrm{mL}$ gas-tight vials (fig. $2 B$ ), and sent to the commercial laboratory (W.L. Gore \& Associates, Inc.) for analysis by gas chromatography/mass spectrometry using a modification of USEPA method 8260/8270 to include thermal desorption of the adsorbed soil gas from the sampler. The laboratory is in compliance with Good Laboratory Practices and ISO Guide 25 (International Organization for Standardization, 1990). The soil-gas contaminant results are expressed as mass of contaminant (units of micrograms) and provide qualitative screening-level data. A value of 0.00 (reporting format of W.L. Gore \& Associates, Inc.) is reported for combined mass or concentration if the individual compounds included in the combined value were not detected above the MDLs and at least one of the individual compounds was reported as below detection level.

Results of passive soil-gas surveys can indicate the presence of particular contaminants. The results, however, do not indicate whether the detection was derived from free product, from residual-phase adsorbed material or vapors in the unsaturated zone, or from the dissolved-phase material in shallow and deep groundwater (unless the module is deployed so that it comes in direct contact with water). In general, higher soil-gas mass in a sample tends to be related to the presence of residual contamination or free product that is close to the land surface where the soil-gas sampler is located. If such source material is located at greater depths, however, the soil-gas contaminant mass generally will be lower. A lower value near known sources of contamination may be due to various attenuation processes that affect the soil-gas mass prior to detection. In both cases, however, the soil-gas samplers help to rapidly indicate the presence or absence of contaminants. The passive soil-gas approach was approved for use at Fort Gordon by the Hazardous Waste Management Branch, Georgia Environmental Protection Department (William Powell, P.E., Environmental Engineer, Department of Defense Remediation Unit, oral commun., 2008).

\section{8th Street Site}

A passive soil-gas survey was conducted at the 8th Street site during June and August 2011. On June 29, 2011, 35 soil-gas samplers were deployed, and 20 soil-gas samplers were deployed on August 8, 2011, for a total of 55 soil-gas samplers (fig. 4). The soil-gas samplers were placed in a grid pattern to cover the generalized extent of the 8th Street site. Six additional soil-gas samplers were used as trip-blank samplers for the June and August 2011 sampling and were not deployed. Each sampler was installed and retrieved as previously described. A 6- to 10-in.-thick concrete pad covered part of the 8th Street site. Eighteen of the 55 soil-gas samplers deployed in June and August 2011 were placed in boreholes below the concrete pad. The 35 soil-gas samplers that were deployed on June 29, 2011, were removed on July 5, 2011, and the 20 soil-gas samplers deployed on August 8, 2011, were removed on August 12, 2011.

\section{Chamberlain Avenue Site}

A passive soil-gas survey was conducted at the Chamberlain Avenue site during July 2011 when 30 soil-gas samplers were deployed (fig. 5). The soil-gas samplers were placed in a grid pattern to cover the generalized extent of the Chamberlain Avenue site. Four additional soil-gas samplers were used as trip-blank samplers for the July 7, 2011, sampling and were not deployed. Each sampler was installed and retrieved as previously described. A 6- to 10-in.-thick concrete pad covered the Chamberlain Avenue site with the exception of a small sandy area in the northeast portion of the site where two soil-gas samplers were installed. Twentyeight of the soil-gas samplers deployed were placed in boreholes below the concrete pad. The 30 soil-gas samplers were deployed on July 7, 2011, and were removed on July 12, 2011.

\section{2th Street Site}

A passive soil-gas survey was conducted at the 12th Street site during July 2011 when 39 soil-gas samplers were deployed (fig. 6). The soil-gas samplers were placed in a grid pattern to cover the generalized extent of the 12th Street site. Three additional soil-gas samplers were used as trip-blank samplers for the July 18, 2011, sampling and were not deployed. Each sampler was installed and retrieved as previously described. A 6- to 10-in.-thick concrete pad covered part of the 12th Street site. Eighteen of the 39 soil-gas samplers deployed were placed in boreholes below the concrete pad. The 39 soil-gas samplers were deployed on July 18, 2011, and were removed on July 22, 2011. 


\section{Results}

The results of the passive soil-gas survey are presented in this section and used to further delineate the area of contamination related to the former fuel-dispensing sites at 8th Street, Chamberlain Avenue, and 12th Street. The results of these sampling activities indicate that past activities at these sites have resulted in an environmental effect.

\section{Passive Soil-Gas Survey}

The passive soil-gas surveys for the former fueldispensing sites at 8th Street, Chamberlain Avenue, and 12th Street were conducted from June to August 2011. All soil-gas samplers were installed to approximately the same depth. A high soil-gas mass for a particular contaminant generally indicates close proximity to a contaminant source. The passive soil-gas survey results are discussed for the 8th Street, Chamberlain Avenue, and 12th Street sites.

\section{8th Street Site}

Fifty-four of the 55 soil-gas samplers installed during June and August 2011 had detections of TPH mass greater than the MDL of 0.02 microgram ( $\mu$ g; fig. 7; tables 1 and 2). Total petroleum hydrocarbons were detected at a soil-gas mass of $1.0 \mu \mathrm{g}$ or greater in 25 of the 55 soil-gas samplers. Eleven soil-gas samplers had detections of TPH soil-gas mass that exceeded $10 \mu \mathrm{g}$. At the 8th Street site, the samplers with the three highest detections of TPH soil-gas mass greater than $50 \mu \mathrm{g}$ were $53.94,80.47$, and $146.10 \mu \mathrm{g}$ (samplers 662040, 662044 , and 662045, respectively). These samplers were located in the central part of the soil-gas site, which is partially wooded and located south and west of the concrete pad. Because all but one soil-gas sampler contained TPH mass at levels greater than the MDL, it is possible that the boundary of the 8th Street soil-gas site has not been fully assessed with respect to TPH. The TPH detections in 52 of the 55 soil-gas samplers were higher than the highest reported TPH detection of $0.10 \mu \mathrm{g}$ in the six trip blanks (tables 1 and 2).

Detections of BTEX were reported as a combined mass for benzene, toluene, and ortho-xylene with MDLs of $0.01 \mu \mathrm{g}$ and ethylbenzene and meta- and para-xylene with MDLs of $0.01 \mu \mathrm{g}$, but ethylbenzene and meta- and para-xylene were not detected in any of the soil-gas samplers above the MDL (tables 1 and 2). Twenty-three of the 55 soil-gas samplers installed at the 8th Street site had benzene mass greater than or equal to the MDL of $0.01 \mu \mathrm{g}$ (fig. 8). The highest benzene mass of $0.04 \mu \mathrm{g}$ (sampler 662053) was detected in the central part of the 8th Street site adjacent to the concrete pad. Only 10 of the 55 soil-gas samplers detected toluene mass greater than or equal to the MDL of $0.01 \mu \mathrm{g}$ (fig. 9). The soil-gas samplers with the two highest detections of toluene mass of 0.11 and $0.25 \mu \mathrm{g}$ (samplers 662336 and 662045, respectively) were located in the southern part of the soil-gas site. These samplers are located just south of the concrete pad, and the highest toluene mass coincides with the location of the highest TPH mass of $146.10 \mu \mathrm{g}$ (fig. 7). Ortho-xylene mass was detected above the MDL in only one soil-gas sampler. There were no reported detections of BTEX mass in any of the six trip blanks (tables 1 and 2).

Pentadecane was detected at a soil-gas mass of $0.01 \mu \mathrm{g}$ or higher in 5 of the 55 soil-gas samplers at the 8th Street site (fig. 10; tables 1 and 2). Two soil-gas samplers were reported below the detection level of $0.01 \mu \mathrm{g}$ with the remaining 48 samplers reported as nondetections. The highest pentadecane soil-gas mass was $0.42 \mu \mathrm{g}$ (sampler 662347) at the 8th Street site and was located in the northeastern corner of the 8th Street site where former building 51101 existed. The next highest detection of pentadecane soil-gas mass of $0.33 \mu \mathrm{g}$ (sampler 662044) was located near the central part of the site and west of the concrete pad. Undecane and tridecane mass were detected at or above the MDL of $0.01 \mu \mathrm{g}$ in six and three soil-gas samplers, respectively. The highest undecane and tridecane soil-gas mass of 5.98 and $0.19 \mu \mathrm{g}$ (sampler 662347; table 2), respectively, also coincides with the location of the sampler having the highest pentadecane soil-gas mass of $0.42 \mu \mathrm{g}$ (sampler 662347; fig. 10; table 2). There were no reported detections of pentadecane, undecane, or tridecane mass in any of the six trip blanks (tables 1 and 2).

Fewer than one-third of the soil-gas samplers installed at the 8th Street site had chloroform mass greater than or equal to the MDL of $0.01 \mu \mathrm{g}$ (fig. 11; tables 1 and 2). The highest soil-gas chloroform mass of $0.28 \mu \mathrm{g}$ (sampler 662340) was detected in the southern part of the site. Chloroform mass ranging from 0.01 to $0.23 \mu \mathrm{g}$ was detected in 12 soil-gas samplers located throughout the site. There were no reported detections of chloroform mass in any of the six trip blanks (tables 1 and 2).

\section{Chamberlain Avenue Site}

All of the 30 soil-gas samplers installed for this study at the Chamberlain Avenue site had detections of TPH mass greater than the MDL of $0.02 \mu \mathrm{g}$ (fig. 12; table 3). Total petroleum hydrocarbons were detected at a soil-gas mass of 0.87 to $10.0 \mu \mathrm{g}$ in 14 of the 30 soil-gas samplers. Sixteen soil-gas samplers had detections of TPH soil-gas mass greater than $10.0 \mu \mathrm{g}$. The samplers with the four highest detections of TPH soil-gas mass of $340.33,356.36,421.69$, and $426.36 \mu \mathrm{g}$ (samplers 662305, 662309, 662308, and 662300, respectively) were located in the central and northern part of the site. Samplers 662305,662308 , and 662300 coincide with raised islands on the concrete pad where the fuel-dispensing pumps still exist but are nonoperational. Because all soil-gas samplers contained TPH mass at levels greater than the MDL, it is possible that the boundary of the Chamberlain Avenue site has not been fully assessed with respect to TPH. The TPH detections in all the soil-gas samplers were higher than the reported TPH detections in any of the four trip blanks $(0.02 \mu \mathrm{g}$; table 3$)$. 
Detections of BTEX were reported as a combined mass for benzene, toluene, and ortho-xylene with MDLs of $0.01 \mu \mathrm{g}$ and ethylbenzene and meta- and para-xylene with MDLs of $0.02 \mu \mathrm{g}$ (table 3 ). There were no detections of BTEX soil-gas mass in nine of the soil-gas samplers at the Chamberlain Avenue site (fig. 13). Eighteen soil-gas samplers had BTEX soil-gas mass detections of 0.02 to $0.22 \mu \mathrm{g}$ located throughout the site. Three soil-gas samplers had detections of BTEX soil-gas mass greater than $0.22 \mu \mathrm{g}$. Samplers 662318 and 662317 had BTEX soil-gas mass of 0.43 and $0.62 \mu \mathrm{g}$, respectively, and were located in the southeastern part of the site. The highest BTEX soil-gas mass of $0.73 \mu \mathrm{g}$ (sampler 662308) was detected in the central part of the Chamberlain Avenue site and coincides with the second highest detection of TPH mass of $421.69 \mu \mathrm{g}$ (fig. 12). Toluene was the most frequently detected of the BTEX compounds with 16 detections above the MDL. Benzene and ethylbenzene mass were detected above the MDL of $0.01 \mu \mathrm{g}$ in 10 and 3 soil-gas samplers, respectively. Meta-, para-, and ortho-xylene were detected above the MDLs in one-third of the soil-gas samplers and commonly coincided with the presence of toluene. There were no reported detections of BTEX mass in any of the four trip blanks (table 3).

The diesel-range alkanes $\left(\mathrm{C}_{11}, \mathrm{C}_{13}\right.$, and $\left.\mathrm{C}_{15}\right)$ were reported by the laboratory as a combined mass for undecane, tridecane, and pentadecane with MDLs of $0.01 \mu \mathrm{g}$ (table 3). Each of the three diesel compounds were detected in multiple soil-gas samplers with five of the samplers having no detections for the combined diesel mass at the Chamberlain Avenue site (fig. 14). Twenty of the soil-gas samplers had detections of diesel mass that ranged from $0.01 \mu \mathrm{g}$ to less than $10 \mu \mathrm{g}$. Five soil-gas samplers had detections of diesel mass that exceeded $10 \mu \mathrm{g}$ and coincide with TPH detections of soil-gas mass greater than $200 \mu \mathrm{g}$ (table 3; fig. 12). The samplers with the three highest detections of combined diesel mass of 28.65 , 29.80, and $30.97 \mu \mathrm{g}$ (samplers 662308, 662305, and 662300, respectively) at the Chamberlain Avenue site were located near the concrete islands at the three most northern former fueldispensing pumps. Undecane was the most frequently detected diesel compound above the MDL (table 3). There were no reported detections of diesel compounds in any of the four trip blanks (table 3).

Trimethylbenzenes (TMBs) were reported by the laboratory as combined masses of 1,2,4-trimethylbenzene and 1,3,5-trimethylbenzene with MDLs of 0.01 and $0.02 \mu \mathrm{g}$, respectively (table 3 ). Eighteen of the soil-gas samplers at the Chamberlain Avenue site had no detections of TMBs mass (fig. 15). Eight of the soil-gas samplers had TMBs mass ranging from 0 to $0.1 \mu \mathrm{g}$, whereas four soil-gas samplers had detections greater than $0.1 \mu \mathrm{g}$. The highest detection of TMBs soil-gas mass was $1.11 \mu \mathrm{g}$ (sampler 662308) and was located in the central part of the Chamberlain Avenue site near the third most southern former fuel-dispensing pump. There were no reported detections of TMBs in any of the four trip blanks (table 3).
Fewer than half of the 30 soil-gas samplers installed at the Chamberlain Avenue site had PCE mass greater than the MDL of $0.02 \mu \mathrm{g}$ (fig. 16; table 3). Nineteen of the soil-gas samplers had detections of PCE mass greater than or equal to $0.03 \mu \mathrm{g}$. The highest soil-gas PCE mass of $0.90 \mu \mathrm{g}$ (sampler 662294) was detected in the northeastern part of the site in a grassy area near the concrete pad. There were no reported detections of PCE in any of the four trip blanks (table 3).

Naphthalene and 2-methyl-naphthalene were the only other compounds specifically reported as exceeding the MDL of $0.02 \mu \mathrm{g}$ at the Chamberlain Avenue site (table 3). The highest soil-gas naphthalene mass of $0.25 \mu \mathrm{g}$ (sampler 662308) was detected in the central part of the Chamberlain Avenue site near the third most southern former fueldispensing pump and coincides with the highest detection of BTEX mass of $0.73 \mu \mathrm{g}$ (table 3; fig. 13). The highest detection of 2-methyl-naphthalene soil-gas mass of $1.82 \mu \mathrm{g}$ (sampler 662309) was located in the central part of the Chamberlain Avenue site. There were no reported detections of naphthalene and 2-methyl-naphthalene above the MDL in any of the four trip blanks (table 3 ).

Octane is a component of gasoline and was detected in four soil-gas samplers above the MDL of $0.02 \mu \mathrm{g}$. The highest octane soil-gas mass was $0.11 \mu \mathrm{g}$, which was located at one of the former fuel-dispensing pumps at the Chamberlain Avenue site, and coincides with the highest BTEX soil-gas mass of $0.73 \mu \mathrm{g}$ and the second highest detection of TPH mass of $421.69 \mu \mathrm{g}$ (sampler 662308; table 3; figs. 12, 13).

\section{2th Street Site}

All 39 soil-gas samplers installed at the 12th Street site had detections of TPH mass greater than the MDL of $0.02 \mu \mathrm{g}$ (fig. 17; table 4). Total petroleum hydrocarbon was detected at a soil-gas mass of 0.15 to $2.0 \mu \mathrm{g}$ in 24 of the 39 soil-gas samplers. Eleven soil-gas samplers had detections of TPH mass greater than $2.0 \mu \mathrm{g}$ but less than $10.0 \mu \mathrm{g}$. The soil-gas samplers with the two highest detections of TPH mass of 19.57 and $24.37 \mu \mathrm{g}$ (samplers 662232 and 662200 , respectively) were located in the northern part of the 12th Street site. Sampler 662200 coincided with a raised island on the concrete pad where the northernmost fuel-dispensing pump once existed, and sampler 662232 was located in an open area west of the concrete pad in the northwest corner of the site. Because all soil-gas samplers contained TPH mass at levels greater than the MDL, it is possible that the boundary of the 12th Street site has not been fully assessed with respect to TPH. The TPH detections in all the soil-gas samplers were higher than the reported TPH detections in any of the three trip blanks (table 4).

Detections of BTEX were reported as a combined mass for benzene, toluene, and ortho-xylene with MDLs of $0.01 \mu \mathrm{g}$, and ethylbenzene and meta- and para-xylene with MDLs of $0.02 \mu \mathrm{g}$; however, there were no reported detections for benzene, ethylbenzene, or xylene above the respective MDLs (table 4). Only four of the 39 soil-gas samplers had 
detections of toluene mass greater than the MDL of $0.01 \mu \mathrm{g}$ (fig. 18; table 4). Three of the soil-gas samplers with toluene mass greater than the MDL were located in the northern part of the 12th Street site. The highest detection of toluene soilgas mass of $0.72 \mu \mathrm{g}$ (sampler 662222) was located along the southwest corner of the concrete pad. There were no reported detections of toluene in any of the three trip blanks (table 4).

The diesel-range alkanes $\left(\mathrm{C}_{11}, \mathrm{C}_{13}\right.$, and $\left.\mathrm{C}_{15}\right)$ were reported by the laboratory as a combined mass for undecane, tridecane, and pentadecane with MDLs of $0.01 \mu \mathrm{g}$ (fig. 19; table 4). At least one of the three diesel compounds was detected in five of the samplers at the 12th Street site. Four of the soil-gas samplers had detections of diesel compounds that ranged from 0 to $0.02 \mu \mathrm{g}$. The highest soil-gas combined diesel mass of $0.65 \mu \mathrm{g}$ (sampler 662223) was detected in the southernmost part of the 12th Street site. There were no reported detections of diesel compounds in any of the four trip blanks (table 4).

Only one soil-gas sampler had detections of TCE and 1,4-dichlorobenzene (1,4-DCB) mass greater than the MDLs of $0.02 \mu \mathrm{g}$ and $0.01 \mu \mathrm{g}$, respectively (table 4). Trichloroethylene and 1,4-DCB each with a mass of $0.05 \mu \mathrm{g}$ were detected in soil-gas sampler 662232 in the northern part of the 12th Street site and coincide with high detections of TPH, toluene, and the diesel-range alkane pentadecane (figs. 17, 18, and 19, respectively). Therefore, it is possible that the boundary of the 12th Street site has not been fully assessed. There were no reported detections of TCE or 1,4-DCB in any of the three trip blanks (table 4).

Chloroform and 1,2,4-trimethylbenzene were the only other compounds reported as exceeding the MDLs (table 4). Chloroform soil-gas mass was greater than the MDL of $0.01 \mu \mathrm{g}$ in three soil-gas samplers. The highest chloroform soil-gas mass of $0.10 \mu \mathrm{g}$ was detected in soil-gas samplers 662198 and 662204 (table 4). Soil-gas mass as 1,2,4-trimethylbenzene exceeded the MDL of $0.01 \mu \mathrm{g}$ in two soil-gas samplers. There were no reported detections of chloroform or 1,2,4-trimethylbenzene above the MDLs in any of the three trip blanks (table 4).

\section{Summary}

The U.S. Geological Survey, in cooperation with the U.S. Department of the Army Environmental and Natural Resources Management Office of the U.S. Army Signal Center and Fort Gordon, Georgia, assessed soil gas for contaminants at three former fuel-dispensing sites at 8th Street, Chamberlain Avenue, and 12th Street at Fort Gordon, Georgia, from October 2010 to September 2011. The assessment of these former fuel-dispensing sites was conducted to provide environmental contamination data to Fort Gordon personnel pursuant to requirements of the Resource Conversation and Recovery Act Part B Hazardous Waste Permit process.

Soil-gas samplers collected at the 8th Street site during the June and August 2011 soil-gas surveys had elevated masses above the method detection level (MDL) for total petroleum hydrocarbons (TPH), gasoline-related compounds benzene, toluene, and ortho-xylene, diesel-range alkanes undecane, tridecane, and pentadecane, and chloroform. Total petroleum hydrocarbons were detected in 54 of the 55 soil-gas samplers. Three of the samplers had detections of TPH mass greater than 50 micrograms $(\mu \mathrm{g})$, and the highest detection of TPH mass was $146.10 \mu \mathrm{g}$. Benzene mass exceeded the MDL of $0.01 \mu \mathrm{g}$ in 23 soil-gas samplers, and toluene was detected in only 10 soil-gas samplers greater than or equal to the MDL of $0.01 \mu \mathrm{g}$. Ortho-xylene mass was detected above the MDL in one soil-gas sampler. The highest undecane, tridecane, and pentadecane soil-gas mass at the 8th Street site was located in the northeastern corner of the site where building 51101 once existed. Chloroform was detected in less than one-third of the soil-gas samplers installed at the 8th Street site.

Thirty soil-gas samplers were installed at the Chamberlain Avenue site during the July 2011 soil-gas survey. Elevated masses above the MDL were identified for $\mathrm{TPH}$, gasoline-related compounds (BTEX), diesel-range alkanes $\left(\mathrm{C}_{11}, \mathrm{C}_{13}\right.$, and $\left.\mathrm{C}_{15}\right)$, trimethylbenzenes, naphthalene, 2-methyl-napthalene, octane, and tetrachloroethylene (PCE). Total petroleum hydrocarbons mass was detected in all 30 of the soil-gas samplers, and the highest detection of TPH soil-gas mass was $426.36 \mu \mathrm{g}$. The gasoline-related compounds and diesel-range alkanes were detected in multiple samplers, and the highest detections were located in the central part of the site near the existing former fuel-dispensing pumps. The highest BTEX soil-gas mass of $0.73 \mu \mathrm{g}$ was detected in sampler 662308 and is located near the third most southern former fuel-dispensing pump. Toluene was the most frequently detected BTEX compound at the Chamberlain Avenue site. Trimethylbenzenes (TMBs) mass was detected in 12 of the soil-gas samplers for this soil-gas survey. At the Chamberlain Avenue site, the highest detection of TMBs mass were located near the raised concrete island at the third most southern former fuel-dispensing pump, the same location with the highest BTEX mass (sampler 662308). Fewer than half of the soil-gas samplers installed at the Chamberlain Avenue site had PCE mass greater than the MDL of $0.02 \mu \mathrm{g}$. The highest soil-gas PCE mass of $0.90 \mu \mathrm{g}$ was detected in a grassy area near the northeast end of the concrete pad. Naphthalene and 2-methyl-napthalene were the only other compounds reported as exceeding the MDL. Octane was detected in four soil-gas samplers greater than the MDL of $0.02 \mu \mathrm{g}$. The highest octane soil-gas mass of $0.11 \mu \mathrm{g}$ was detected at the same location near the former fuel-dispensing pump with the highest BTEX and TMBs soil-gas masses (sampler 662308).

Soil-gas samplers collected at the 12th Street site during the July 2011 soil-gas survey had elevated masses above the MDL for TPH, toluene, undecane, tridecane, and pentadecane (diesel-range alkanes), trichloroethylene (TCE), 1,4-dichlorobenzene (1,4-DCB), chloroform, and 1,2,4-trimethylbenzene. Total petroleum hydrocarbons were detected above the MDL in all 39 soil-gas samplers. Sampler 662200 , with a TPH mass of $24.37 \mu \mathrm{g}$, coincided with a 
raised island on the concrete pad where the northernmost fuel-dispensing pump once existed, and sampler 662232, with a TPH mass of $19.57 \mu \mathrm{g}$, was located in an open area in the northwest corner of the site. The highest detections of TPH soil-gas mass were located in the northern part of the site. Toluene soil-gas mass greater than the MDL of $0.01 \mu \mathrm{g}$ was detected in four of the samplers. The highest diesel soil-gas mass of $0.65 \mu \mathrm{g}$ was detected in a sampler located in the southern part of the 12th Street site. One sampler in the northern part of the 12th Street site (sampler 662232) had detections of TCE and 1,4-DCB soil-gas mass greater than the MDL of 0.02 and $0.01 \mu \mathrm{g}$, respectively, and coincides with high detections of TPH, toluene, and the diesel-range alkane pentadecane. Chloroform and 1,2,4-trimethylbenzene were the only other compounds reported as exceeding the MDLs. Chloroform mass was detected above the MDL in three soil-gas samplers, whereas 1,2,4-trimethylbenzene mass was detected above the MDL in two soil-gas samplers.

\section{Selected References}

American Society for Testing and Materials, 2006, Standard guide for soil gas monitoring in the vadose zone: ASTM D5314-92, $36 \mathrm{p}$.

Briggs, P.H., and Meier, A.L., 2002, The determination of forty-two elements in geological materials by inductively coupled plasma-mass spectrometry, in Taggart, J.E., Jr., ed., 2002, Analytical methods for chemical analysis of geologic and other materials, U.S. Geological Survey: U.S. Geological Survey Open-File Report 02-223-I, 14 p.

Caldwell, A.W., Falls, W.F., Guimaraes, W.B, Ratliff, W.H., Wellborn, J.B., and Landmeyer, J.E., 2011, Assessment of soil-gas and soil contamination at the South Prong Creek Disposal Area, Fort Gordon, Georgia, 2009-2010: U.S. Geological Survey Open-File Report 2011-1079, 34 p.

Falls, W.F., Caldwell, A.W., Guimaraes, W.B, Ratliff, W.H., Wellborn, J.B., and Landmeyer, J.E., 2011, Assessment of soil-gas and soil contamination at the former Military Police Range, Fort Gordon, Georgia, 2009-2010: U.S. Geological Survey Open-File Report 2011-1095, 24 p.
Gregory, M.B., Stamey, T.C., and Wellborn, J.B., 2001, Ecological characterization of streams, and fish-tissue analysis for mercury and lead at selected locations, Fort Gordon, Georgia, June 1999 to May 2000: U.S. Geological Survey Open-File Report 01-203, 24 p.

International Organization for Standardization, 1990, ISO Guide 25-General requirements for the competence of calibration and testing laboratories ( $3 \mathrm{~d}$ ed.): New York, American National Standards Institute.

South Carolina Department of Health and Environmental Control, 2002, Environmental Surveillance and Oversight Program data report, 2002, accessed February 11, 2010, at http://www.scdhec.gov/environment/envserv/docs/esop datarpt_02.pdf.

U.S. Environmental Protection Agency, 1998, Environmental technology verification report, soil gas sampling technology: EPA/600/R-98/095, 44 p. + app.

U.S. Environmental Protection Agency, 2009, Regional screening level tables, accessed January 12, 2010, at http://www.epa.gov/reg3hwmd/risk/human/ rb-concentration_table/Generic_Tables/index.htm.

Williams, L.J., 2007, Hydrogeology and potentiometric surface of the Dublin and Midville aquifer systems in Richmond County, Georgia, January 2007: U.S. Geological Survey Scientific Investigations Map 2982, 1 sheet.

W.L. Gore \& Associates, Inc., 2004, GORE ${ }^{\mathrm{TM}}$ surveys for site assessment \& monitoring, accessed February 28, 2011, at http://www.gore.com/MungoBlobs/239/659/surveys_ environmental_brochure.pdf. 


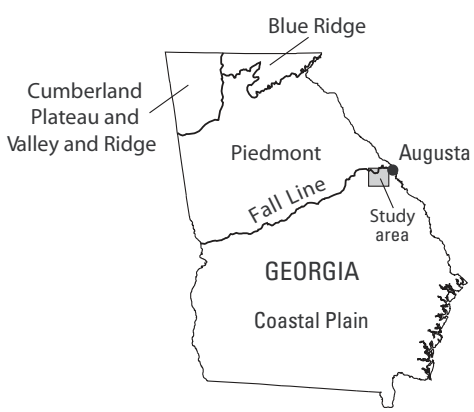

EXPLANATION

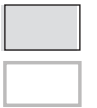

$\square \quad$ FORMER FUEL-DISPENSING SITE
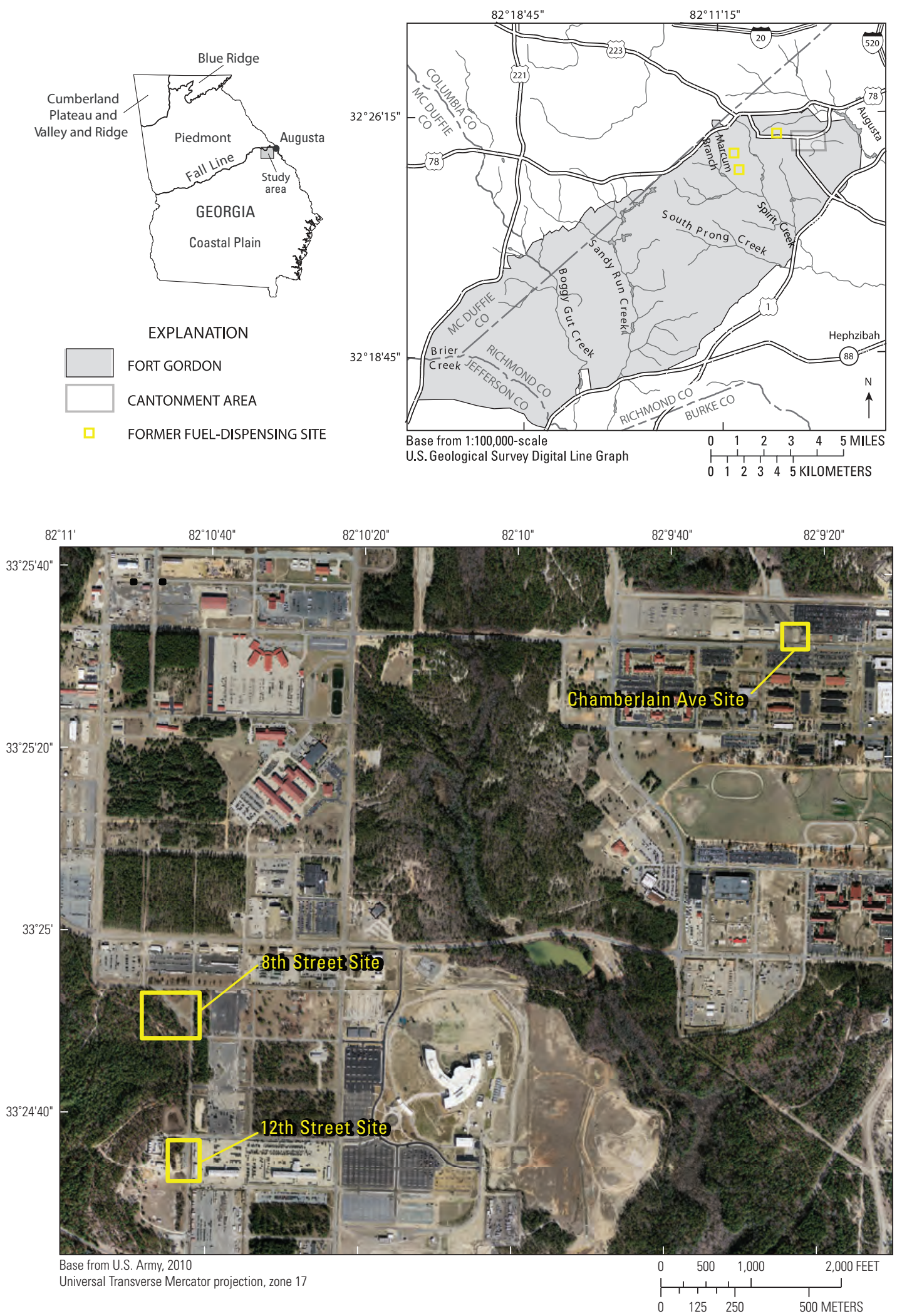

Figure 1. Locations of the 8th Street, Chamberlain Avenue, and 12th Street former fuel-dispensing sites, Fort Gordon, Georgia. 

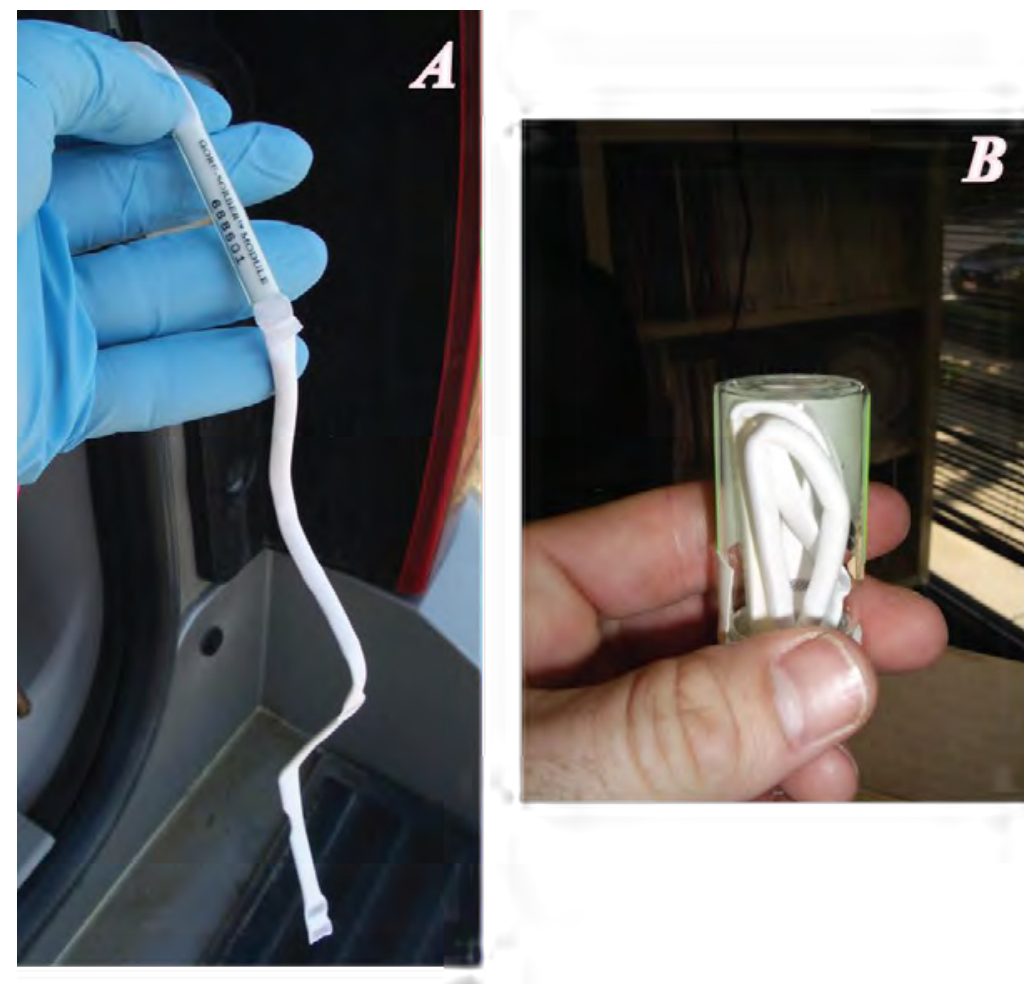

Figure 2. (A) Soil-gas sampler prior to being installed in a shallow borehole and $(B)$ following retrieval from a borehole and prior to shipping to laboratory for analysis.

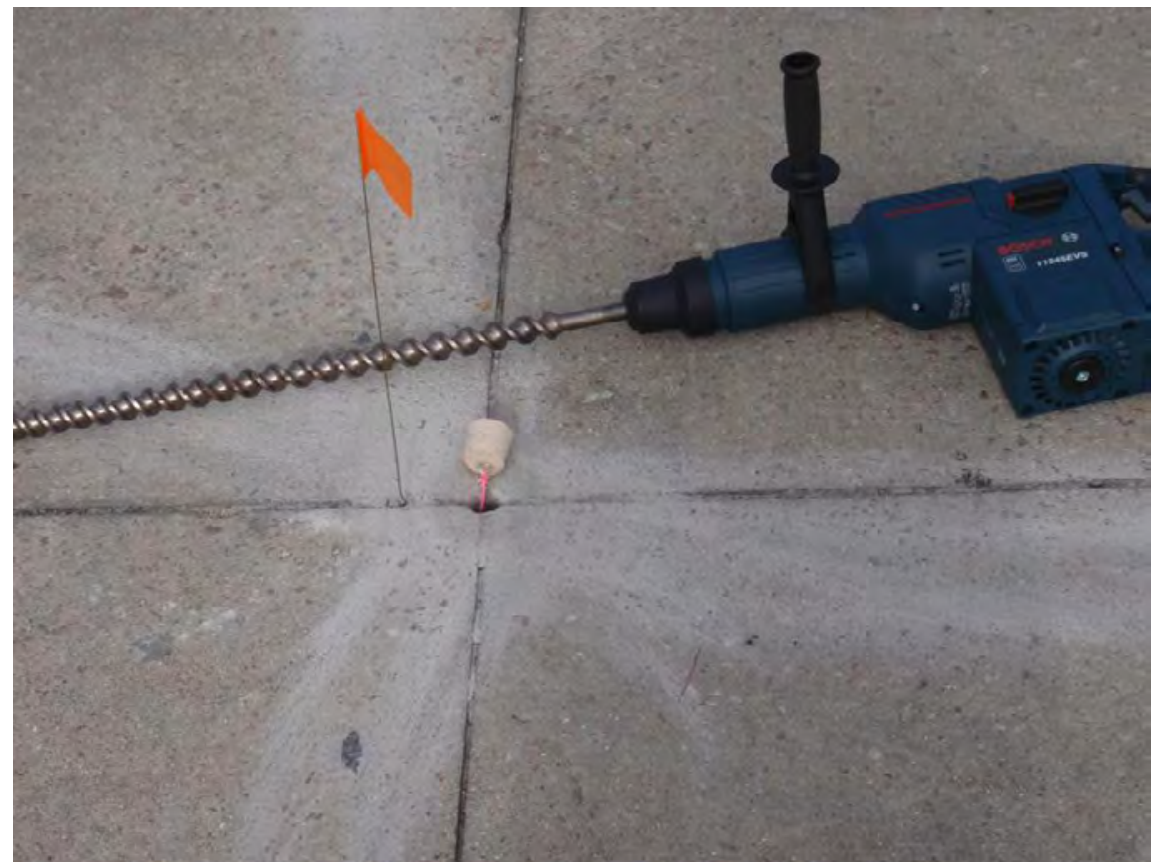

Figure 3. Rotary hammer drill with stainless-steel drill bit used to drill boreholes for installation of the passive soil-gas samplers at the 8th Street, Chamberlain Avenue, and 12th Street sites. 


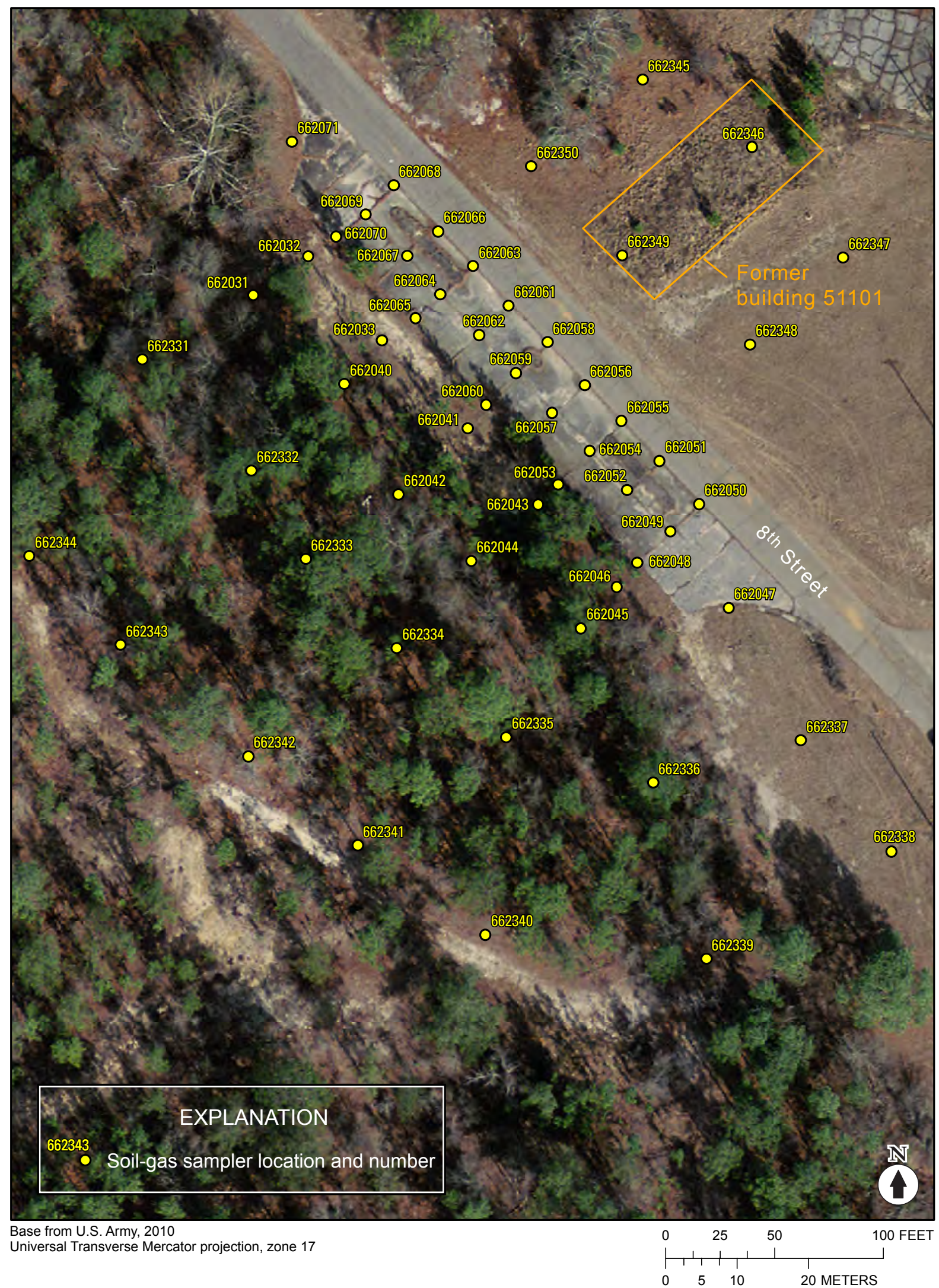

Figure 4. Locations of soil-gas samplers, 8th Street site, Fort Gordon, Georgia, June 29-August 12, 2011. 


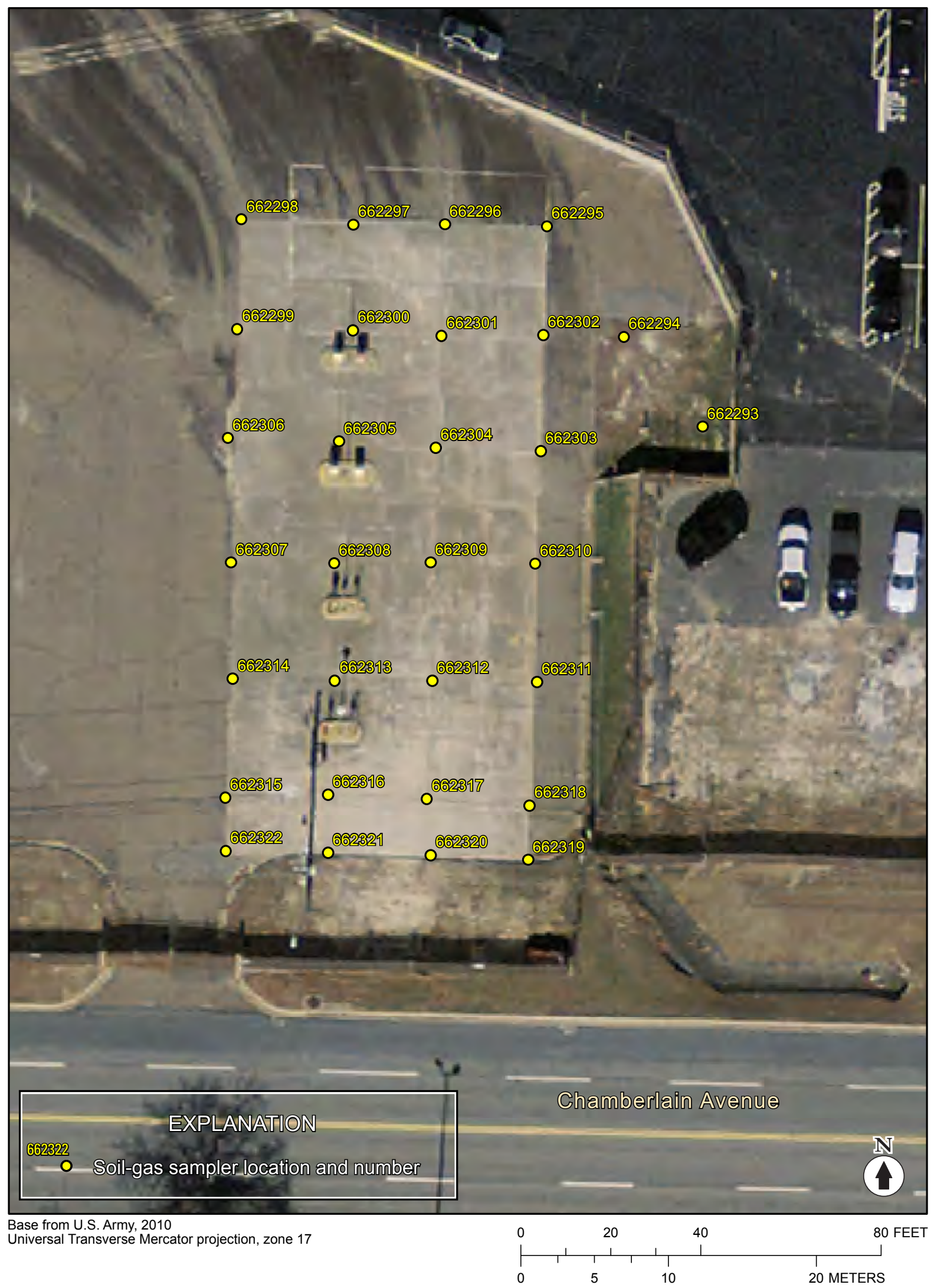

Figure 5. Locations of soil-gas samplers, Chamberlain Avenue site, Fort Gordon, Georgia, July 7-12, 2011. 


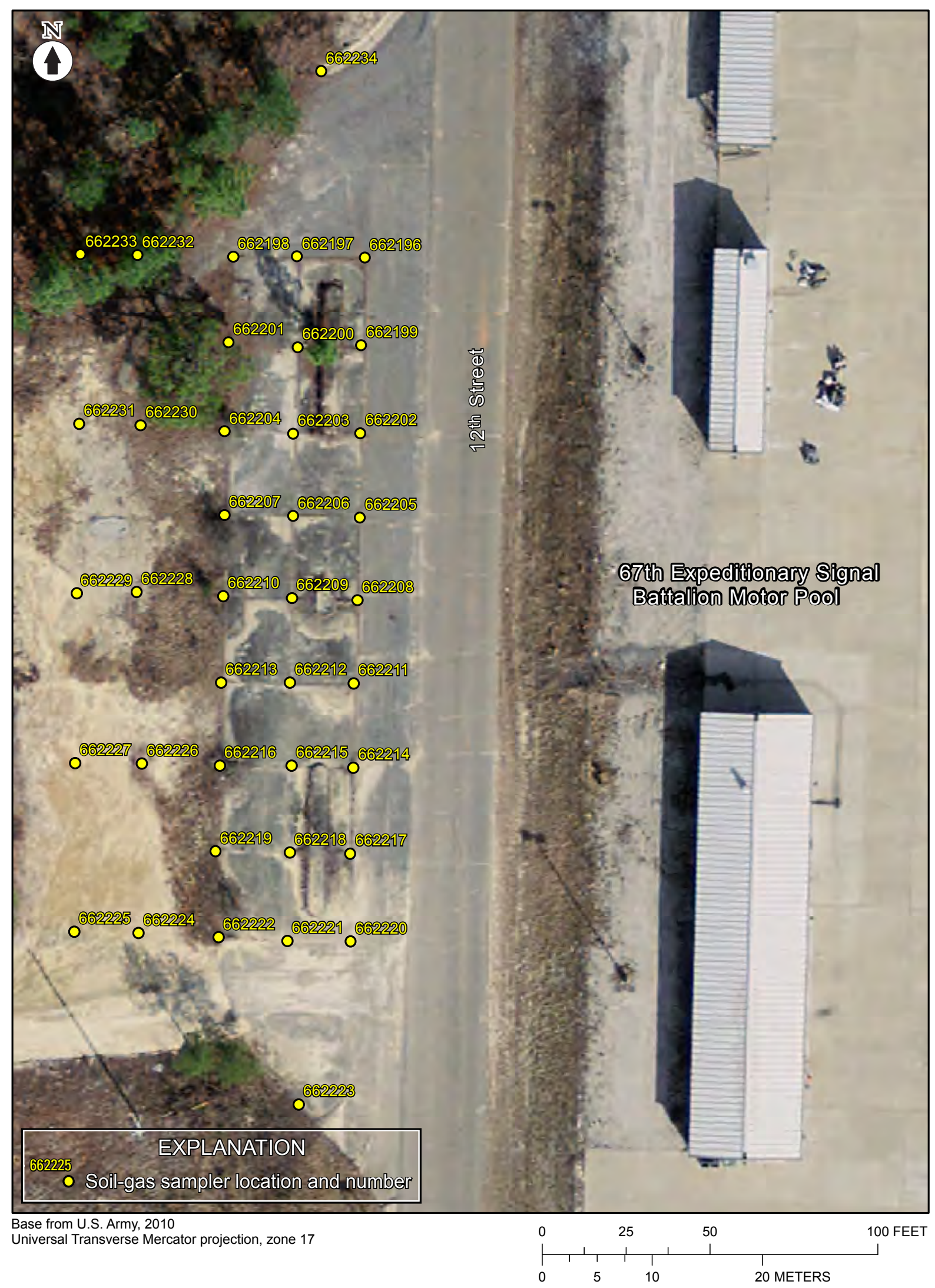

Figure 6. Locations of soil-gas samplers, 12th Street site, Fort Gordon, Georgia, July 18-22, 2011. 


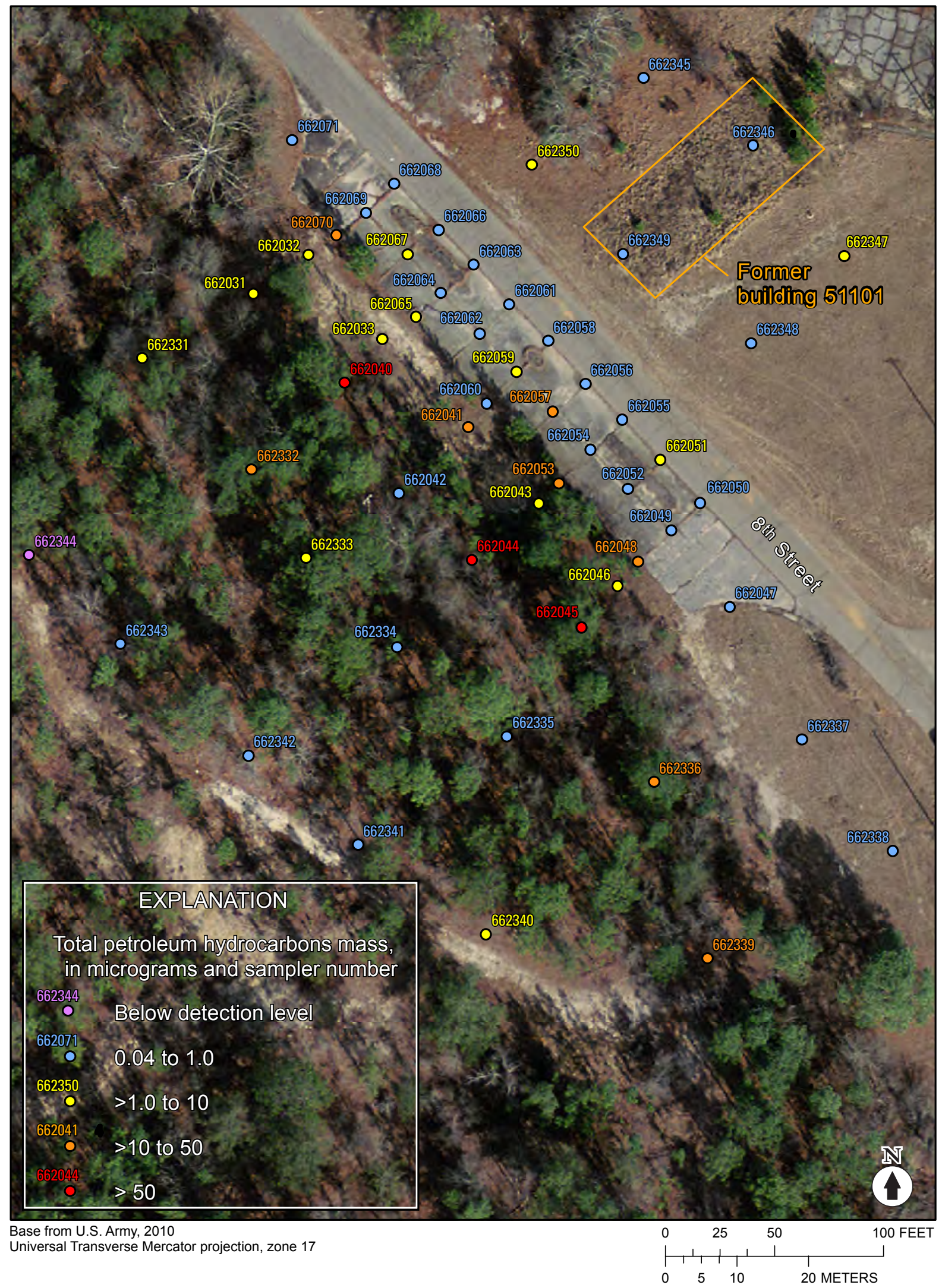

Figure 7. Detections of total petroleum hydrocarbons mass in soil-gas samplers, 8th Street site, Fort Gordon, Georgia, June 29-August 12, 2011. 


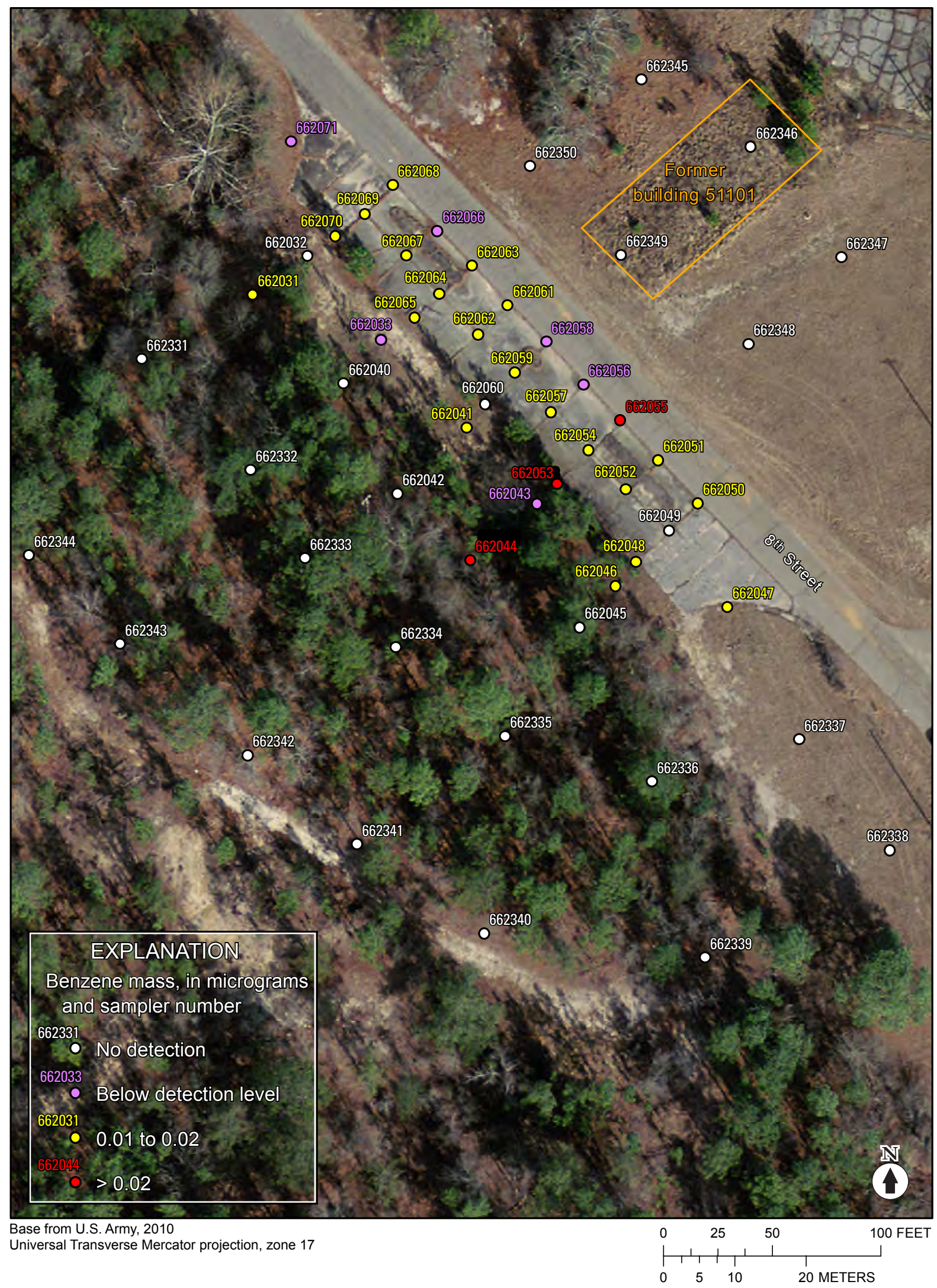

Figure 8. Detections of benzene mass in soil-gas samplers, 8th Street site, Fort Gordon, Georgia, June 29-August 12, 2011. 


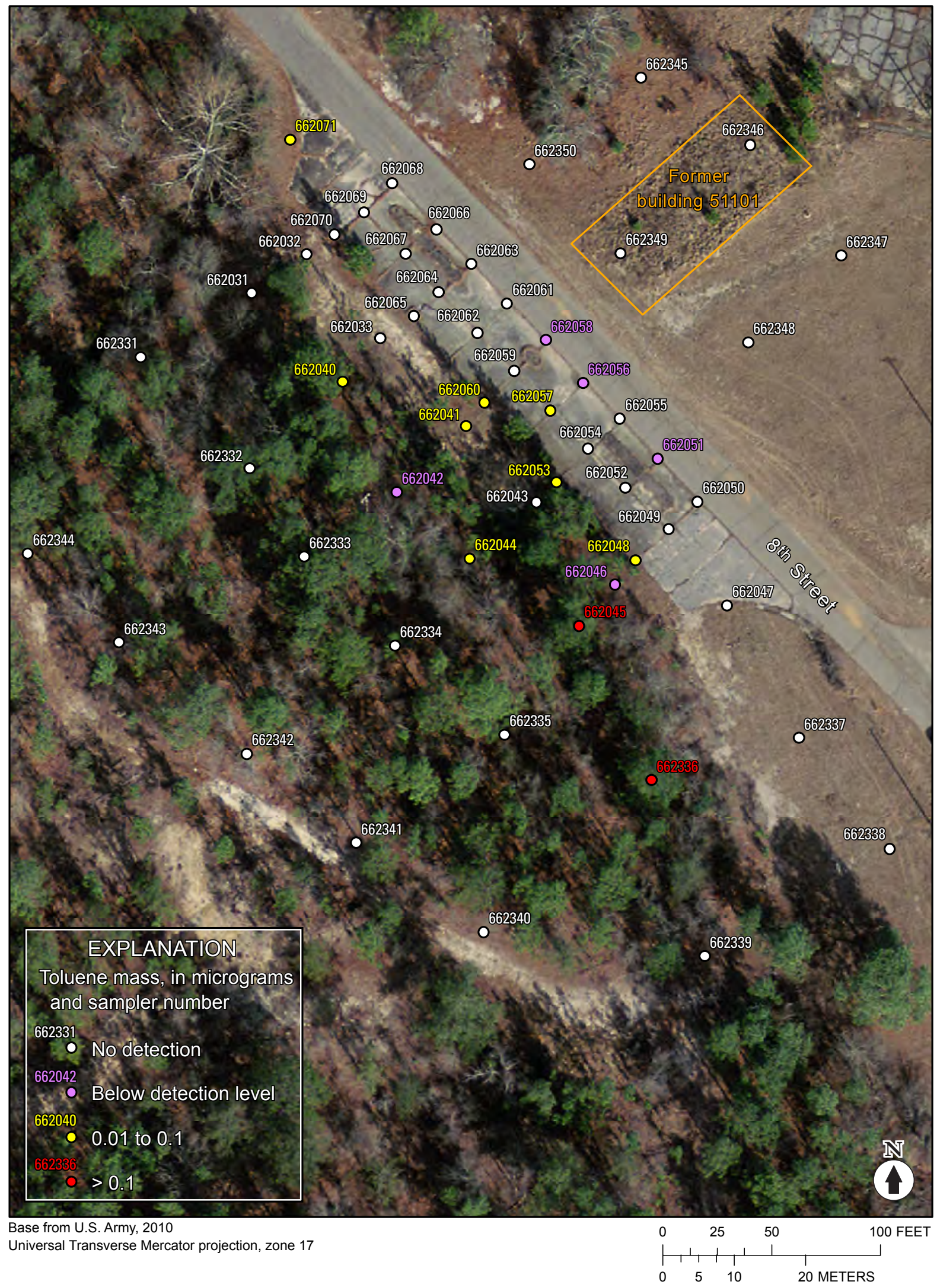

Figure 9. Detections of toluene mass in soil-gas samplers, 8th Street site, Fort Gordon, Georgia, June 29-August 12, 2011. 


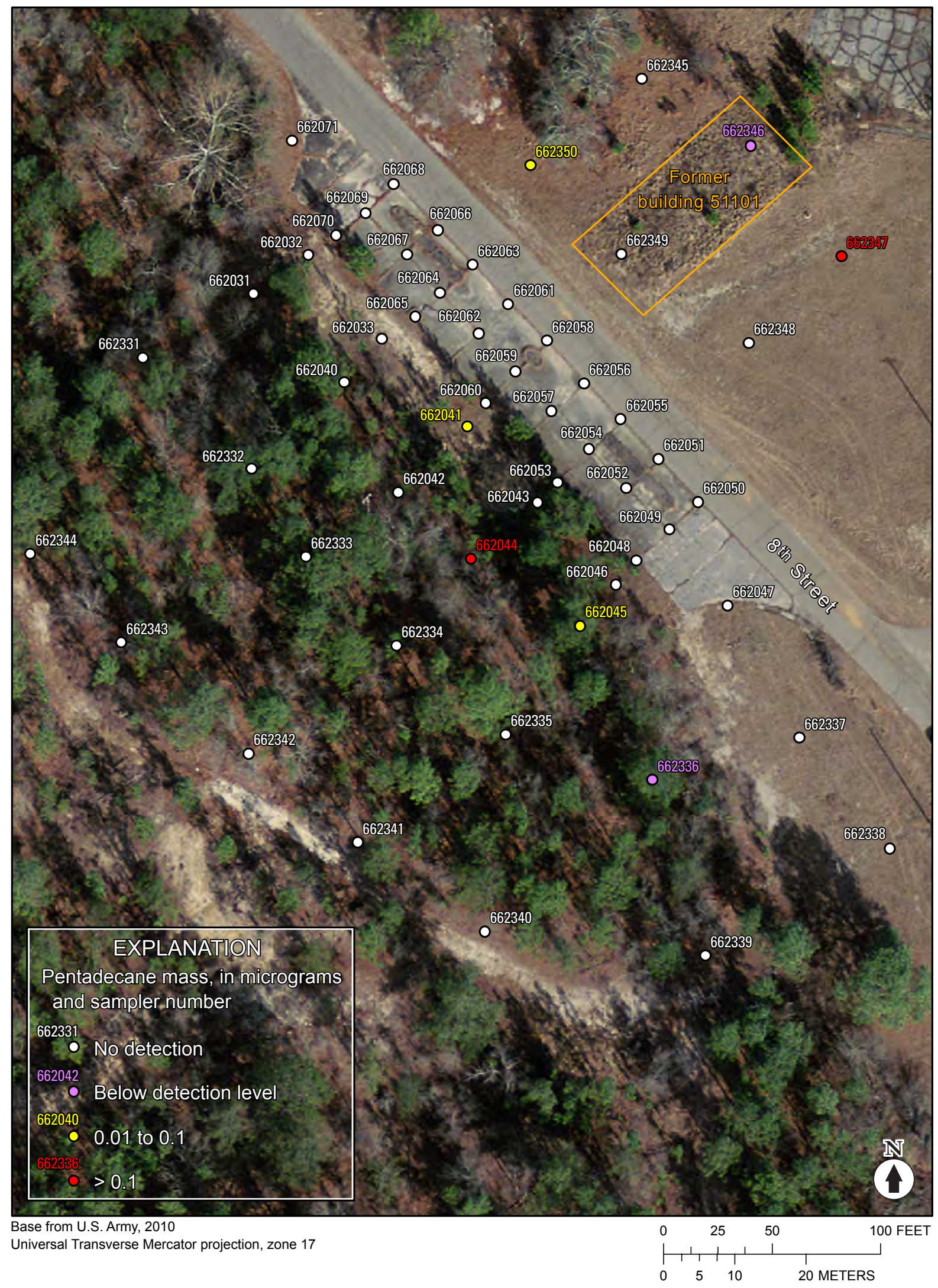

Figure 10. Detections of pentadecane mass in soil-gas samplers, 8th Street site, Fort Gordon, Georgia, June 29-August 12, 2011. 


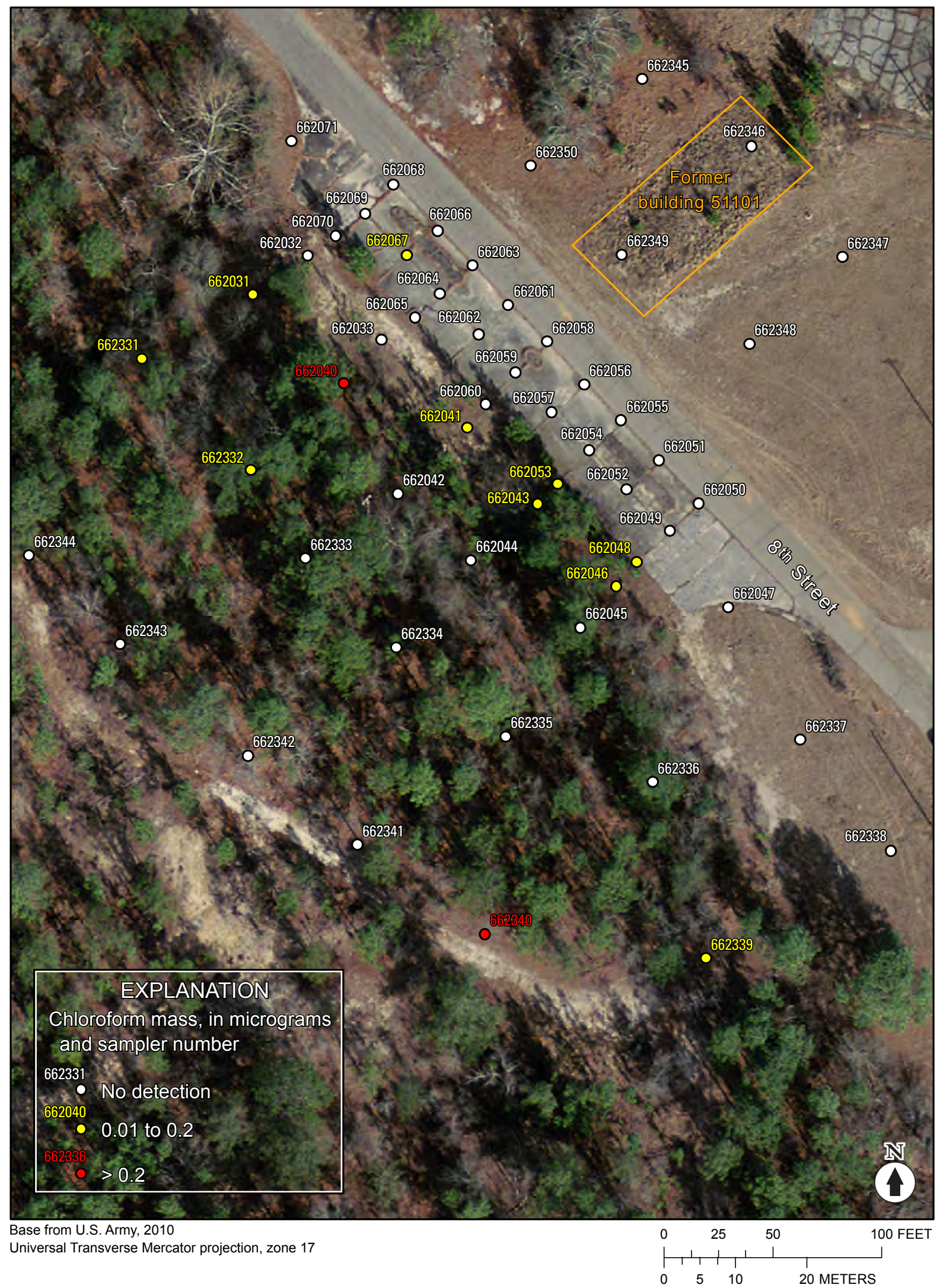

Figure 11. Detections of chloroform mass in soil-gas samplers, 8th Street site, Fort Gordon, Georgia, June 29-August 12, 2011. 


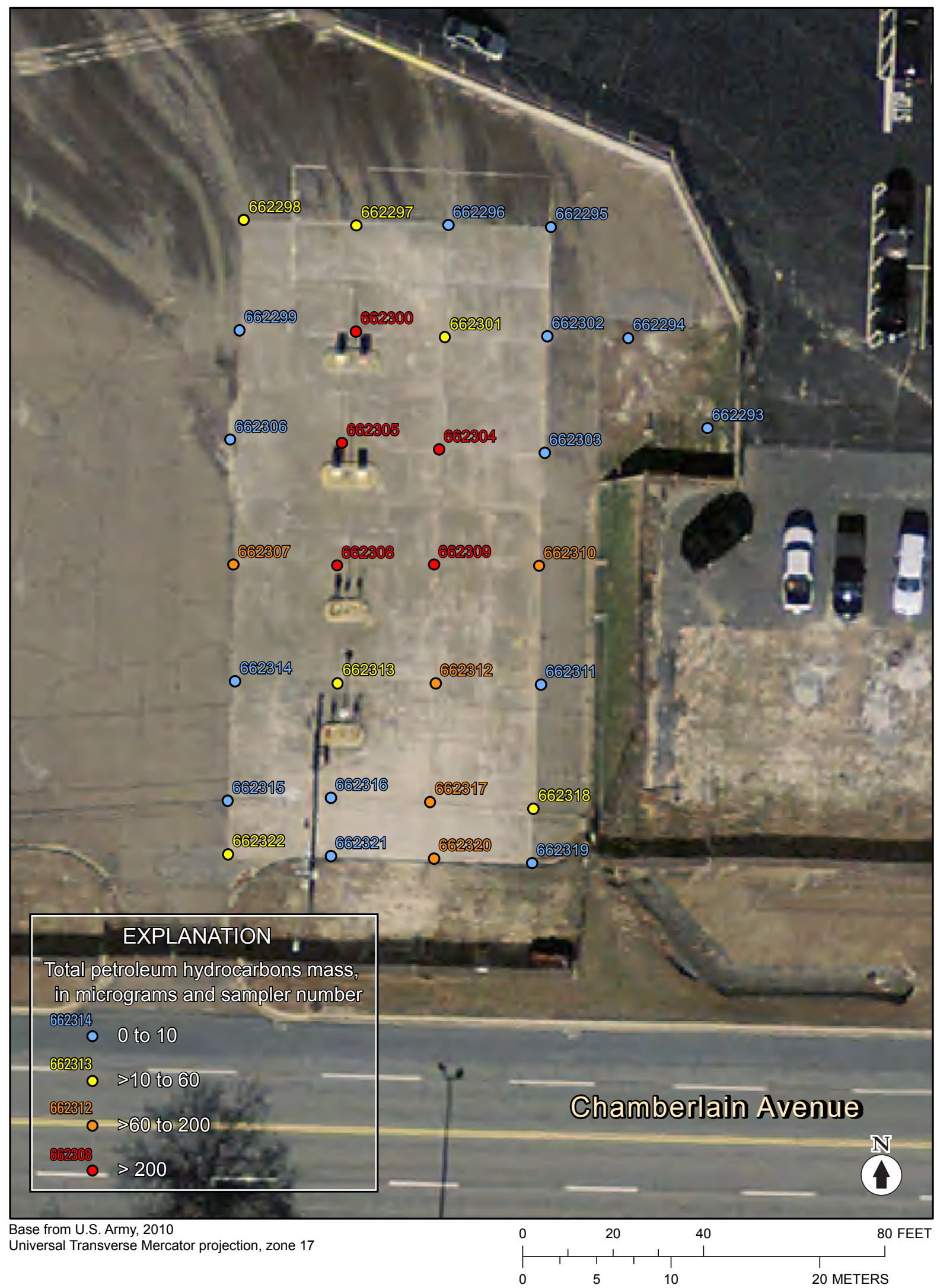

Figure 12. Detections of total petroleum hydrocarbons mass in soil-gas samplers, Chamberlain Avenue site, Fort Gordon, Georgia, July 7-12, 2011. 


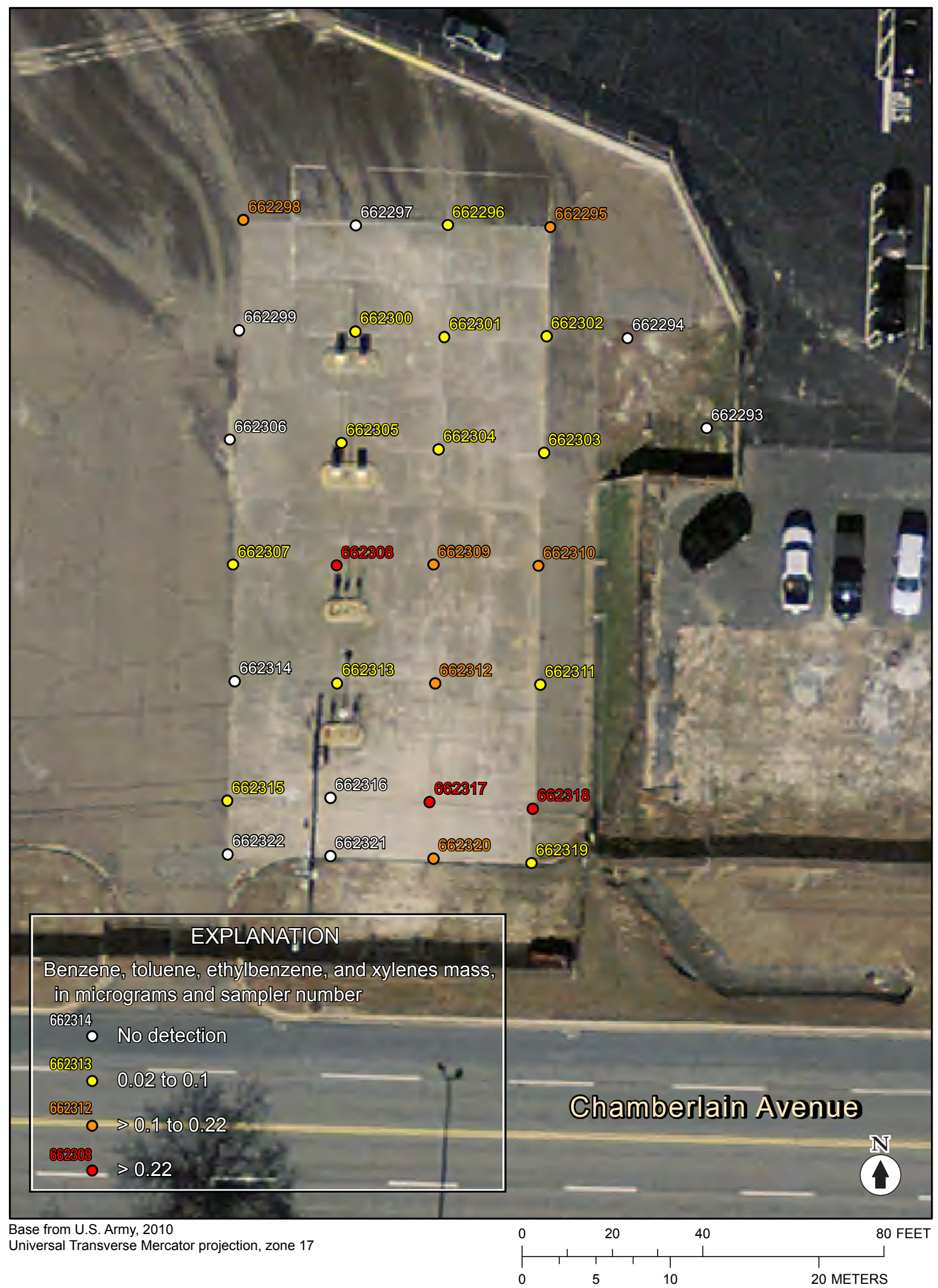

Figure 13. Detections of combined mass of benzene, toluene, ethylbenzene, and xylenes in soil-gas samplers, Chamberlain Avenue site, Fort Gordon, Georgia, July 7-12, 2011. 


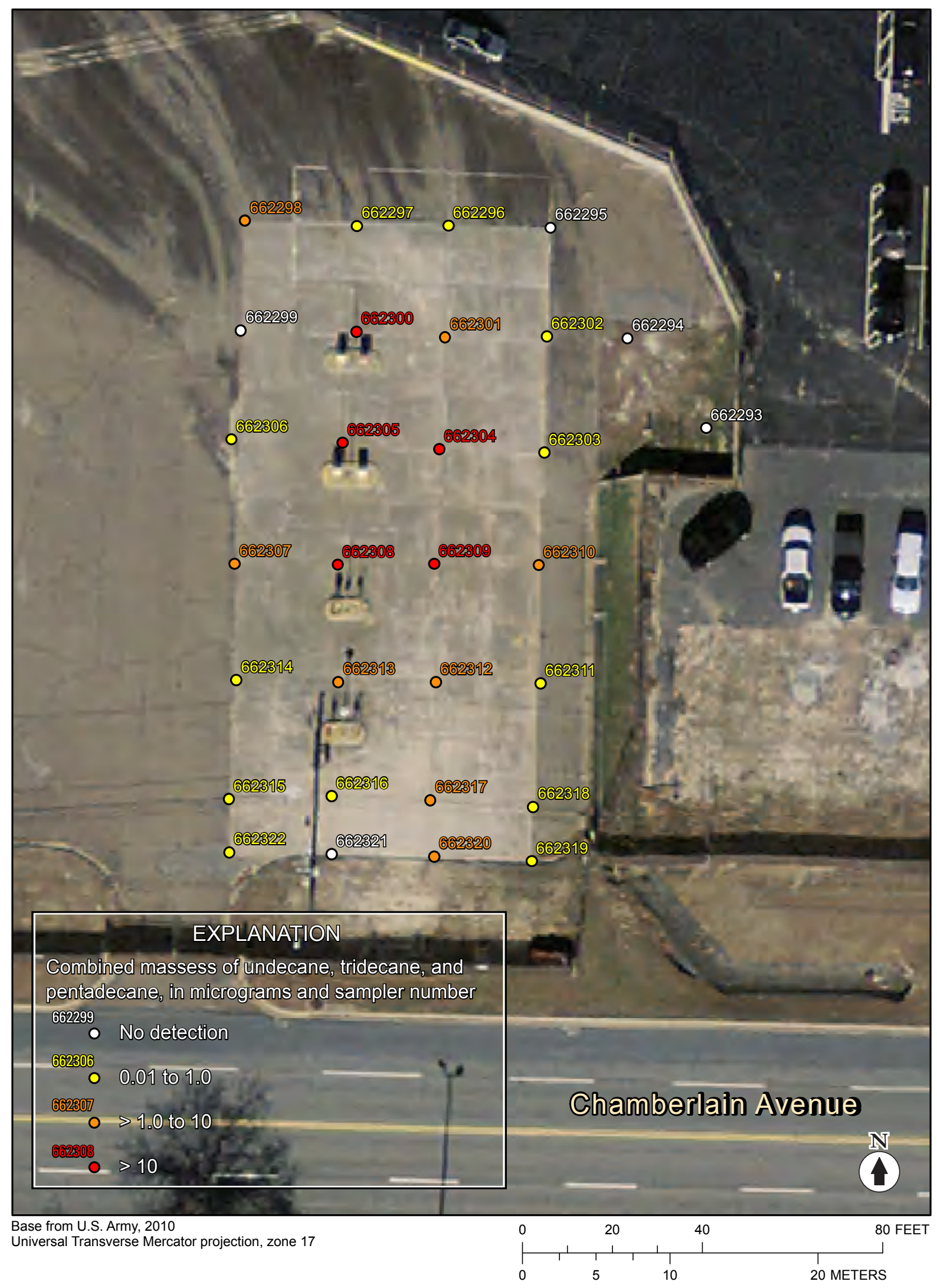

Figure 14. Detections of combined mass of undecane, tridecane, and pentadecane $\left(\mathrm{C}_{11}, \mathrm{C}_{13}\right.$, and $\mathrm{C}_{15}$ diesel compounds $)$ in soil-gas samplers, Chamberlain Avenue site, Fort Gordon, Georgia, July 7-12, 2011. 


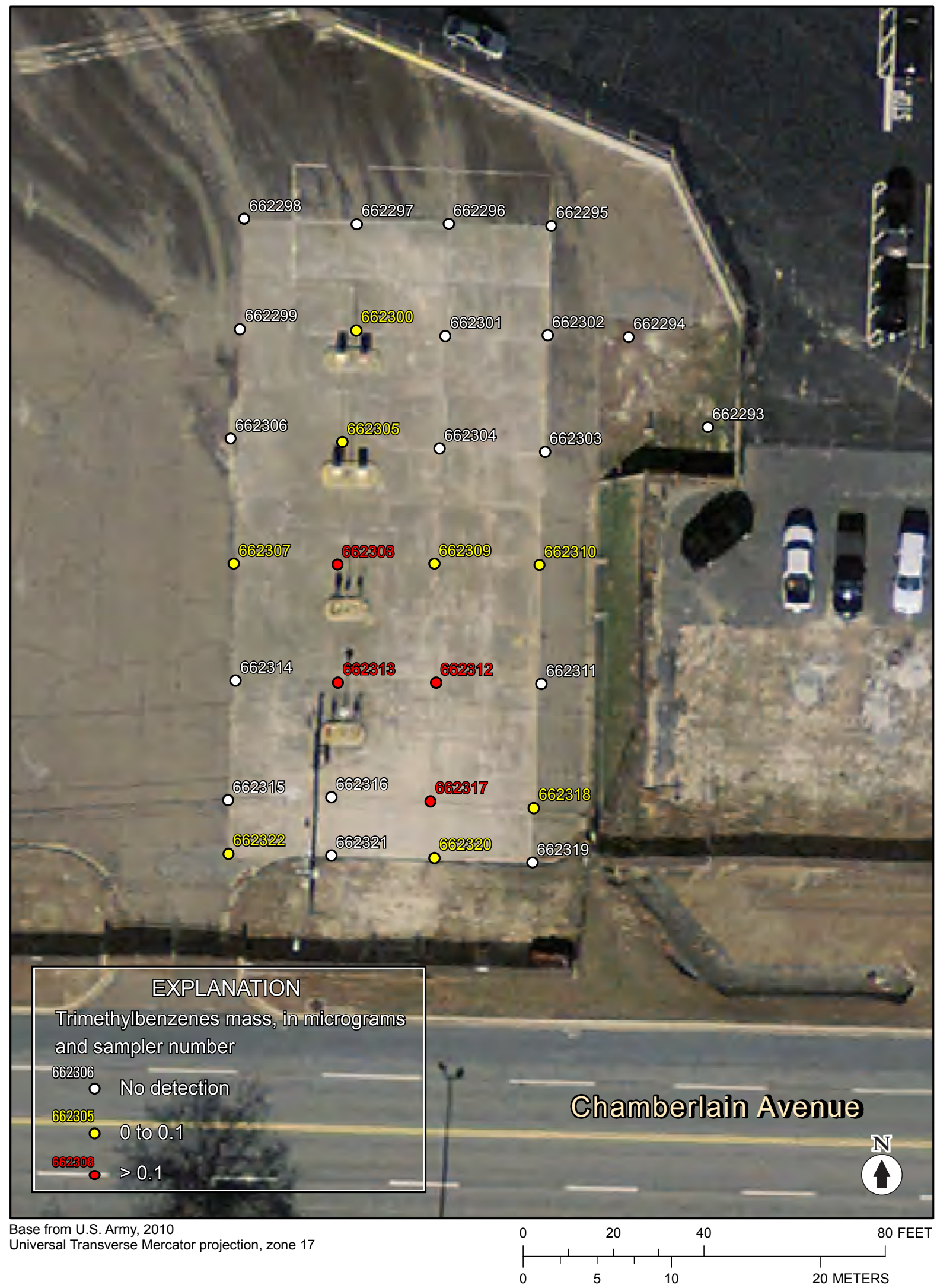

Figure 15. Detections of trimethylbenzenes mass in soil-gas samplers, Chamberlain Avenue site, Fort Gordon, Georgia, July 7-12, 2011. 


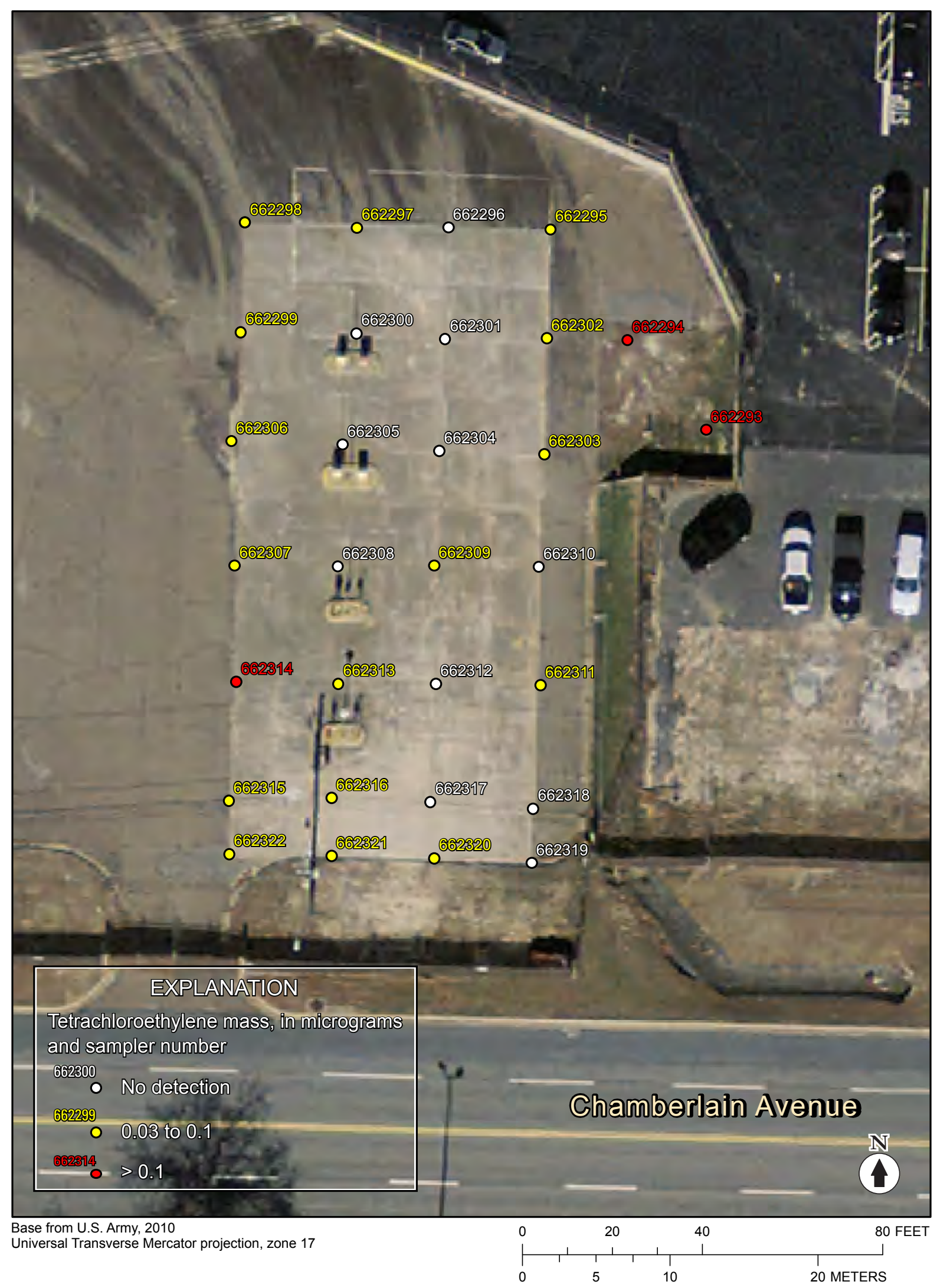

Figure 16. Detections of tetrachloroethylene mass in soil-gas samplers, Chamberlain Avenue site, Fort Gordon, Georgia, July 7-12, 2011. 


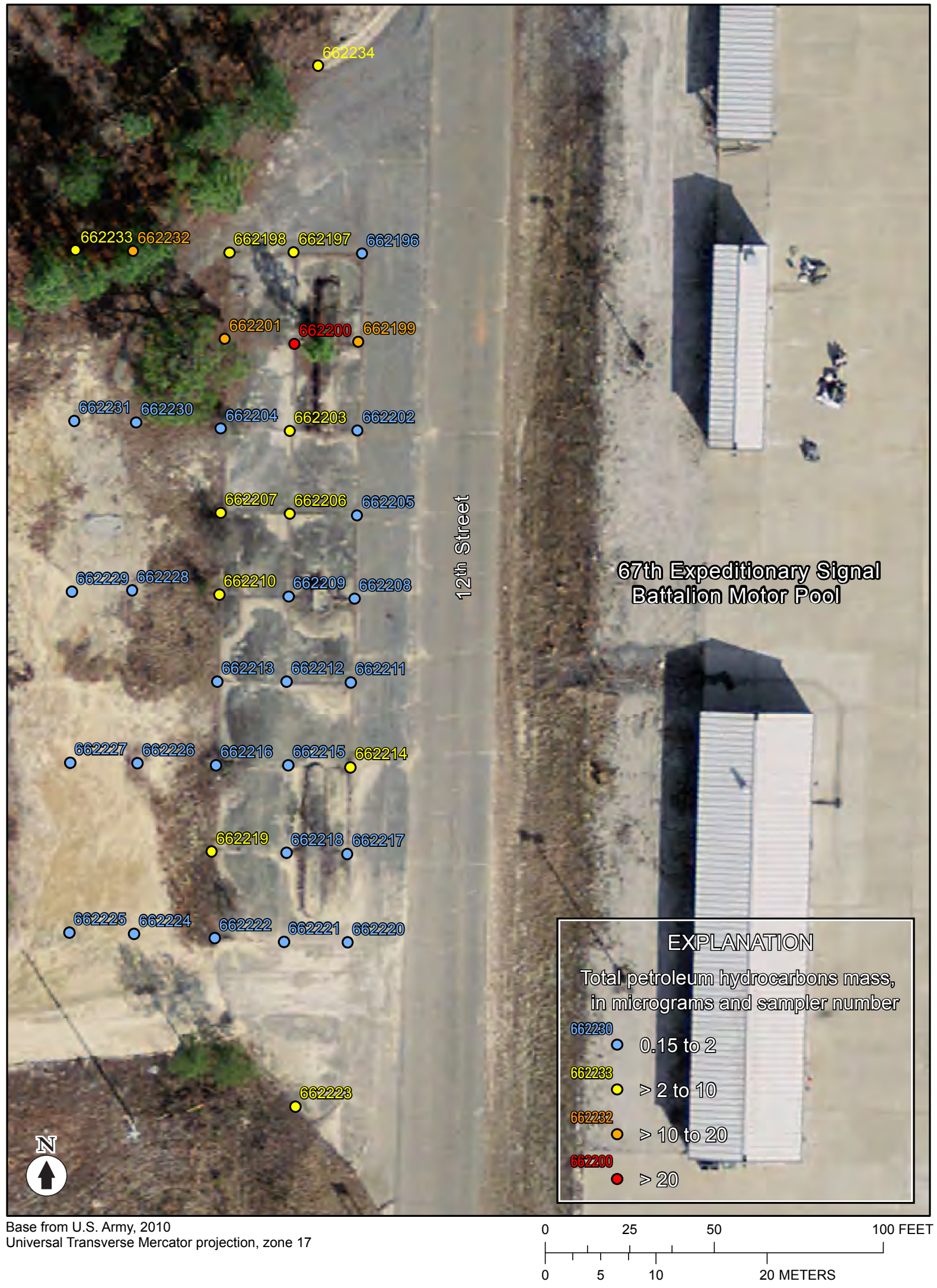

Figure 17. Detections of total petroleum hydrocarbons mass in soil-gas samplers, 12th Street site, Fort Gordon, Georgia, July 18-22, 2011. 


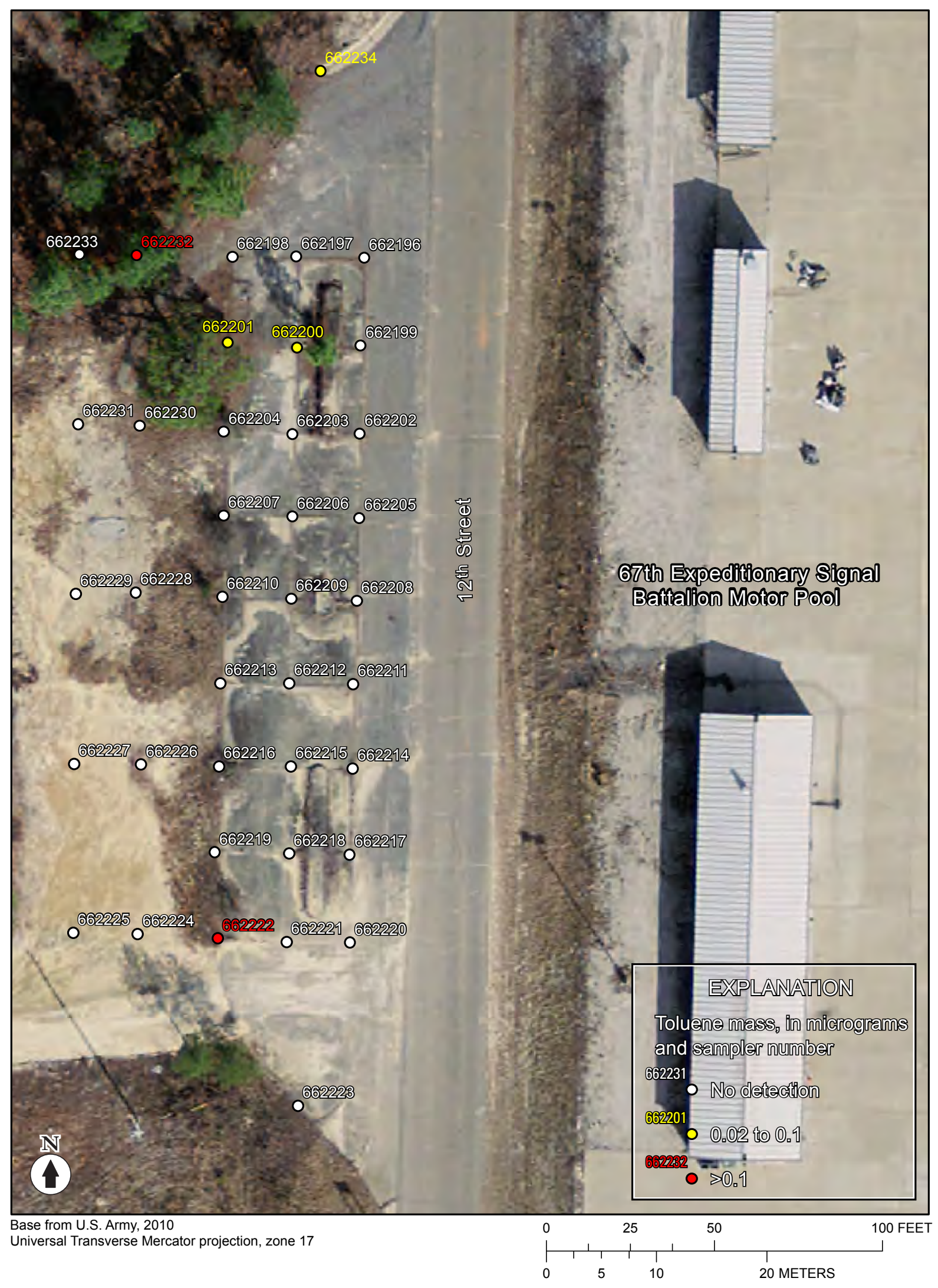

Figure 18. Detections of toluene mass in soil-gas samplers, 12th Street site, Fort Gordon, Georgia, July 18-22, 2011. 


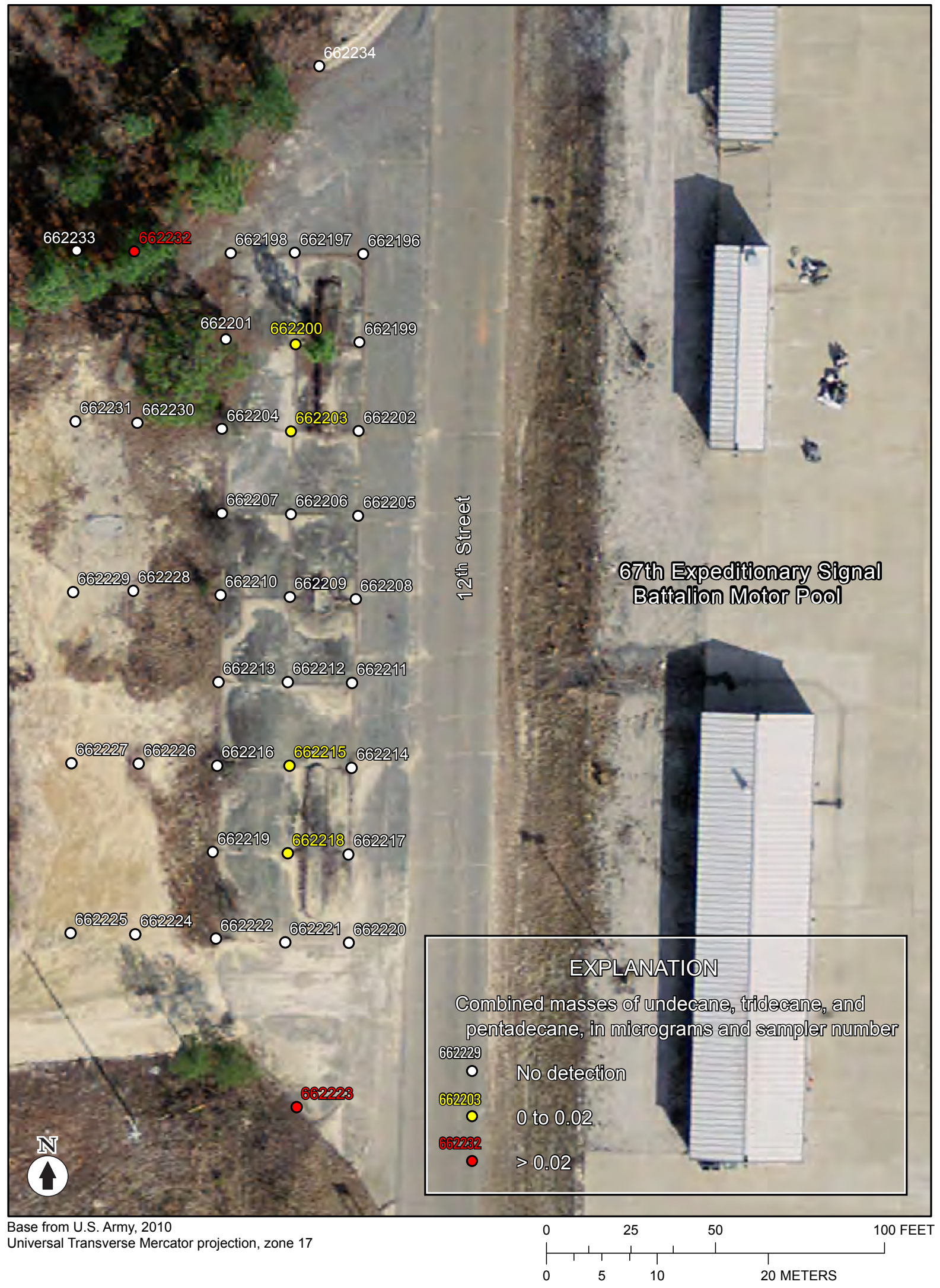

Figure 19. Detections of combined mass of undecane, tridecane, and pentadecane $\left(C_{11}, C_{13}\right.$, and $C_{15}$ diesel compounds) in soil-gas samplers, 12th Street site, Fort Gordon, Georgia, July 18-22, 2011. 
Table 1. Mass of volatile organic compounds detected in soil-gas samplers deployed on June 29, 2011, collected from the 8th Street site, Fort Gordon, Georgia.

[MDL, method detection level; TPH, total petroleum hydrocarbons; $\mu \mathrm{g}$, micrograms; BTEX, benzene, toluene, ethylbenzene, and xylenes; ---, not applicable; $m$, meta; , para; $o$, ortho $\mathrm{C}_{11}, \mathrm{C}_{13}$, and $\mathrm{C}_{15}$, undecane, tridecane, and pentadecane; $c$, cis; $t$, trans; DCE, dichloroethylene; MTBE, methyl tert-butyl ether; DCA, dichloroethane; TCA, trichloroethane; TCE, trichloroethylene; PCE, perchloroethylene; $\mathrm{DCB}$, dichlorobenzene; $\mathrm{CCl}_{4}$, carbon tetrachloride; nd, not detected; bdl, below detection level]

\begin{tabular}{|c|c|c|c|c|c|c|c|c|c|c|c|c|}
\hline $\begin{array}{l}\text { Sampler } \\
\text { Number }\end{array}$ & $\begin{array}{l}\text { TPH } \\
(\mu g)\end{array}$ & $\begin{array}{c}\text { BTEX } \\
\text { ( } \mu \mathrm{g})\end{array}$ & $\begin{array}{c}\text { Benzene } \\
\text { ( } \mu g)\end{array}$ & $\begin{array}{c}\text { Toluene } \\
\text { ( } \mu g)\end{array}$ & $\begin{array}{c}\text { Ethyl- } \\
\text { benzene } \\
(\mu \mathrm{g})\end{array}$ & $\begin{array}{c}m \text {-, } p \text { - } \\
\text { Xylene } \\
(\mu \mathrm{g})\end{array}$ & $\begin{array}{c}\text { o-Xylene } \\
\text { ( } \mu \mathrm{g})\end{array}$ & $\begin{array}{c}C_{11^{\prime}} C_{13^{\prime}} \\
\& C_{15} \\
(\mu g)\end{array}$ & $\begin{array}{c}\text { Undec- } \\
\text { ane } \\
\text { ( } \mu \mathrm{g})\end{array}$ & $\begin{array}{c}\text { Tridec- } \\
\text { ane } \\
\text { ( } \mu \mathrm{g})\end{array}$ & $\begin{array}{l}\text { Penta- } \\
\text { decane } \\
(\mu \mathrm{g})\end{array}$ & $\begin{array}{c}\text { Trimethyl- } \\
\text { benzene } \\
(\mu \mathrm{g})\end{array}$ \\
\hline $\mathrm{MDL}=$ & 0.02 & --- & 0.01 & 0.01 & 0.02 & 0.02 & 0.01 & --- & 0.01 & 0.01 & 0.01 & --- \\
\hline 662031 & 1.28 & 0.01 & 0.01 & nd & nd & nd & nd & 0.03 & 0.03 & nd & nd & nd \\
\hline 662032 & 1.24 & nd & nd & nd & nd & nd & nd & nd & nd & nd & nd & nd \\
\hline 662033 & 1.15 & 0.00 & bdl & nd & nd & nd & nd & nd & nd & nd & nd & nd \\
\hline $662040 \mathrm{DL}^{1}$ & 53.94 & 0.03 & nd & 0.03 & nd & nd & nd & nd & nd & nd & nd & nd \\
\hline 662041 & 17.05 & 0.04 & 0.02 & 0.03 & nd & nd & nd & 0.01 & nd & nd & 0.01 & nd \\
\hline 662042 & 0.81 & 0.00 & nd & bdl & nd & nd & nd & nd & nd & nd & nd & nd \\
\hline 662043 & 1.88 & 0.00 & bdl & nd & nd & nd & nd & nd & nd & nd & nd & nd \\
\hline 662044 & 80.47 & 0.04 & 0.03 & 0.01 & nd & bdl & nd & 0.33 & nd & nd & 0.33 & nd \\
\hline $662045 \mathrm{DL}^{1}$ & 146.10 & 0.25 & nd & 0.25 & nd & nd & nd & 0.02 & nd & nd & 0.02 & nd \\
\hline 662046 & 4.30 & 0.01 & 0.01 & bdl & nd & nd & nd & nd & nd & nd & nd & nd \\
\hline 662047 & 0.27 & 0.02 & 0.02 & nd & nd & nd & nd & nd & nd & nd & nd & nd \\
\hline 662048 & 13.14 & 0.03 & 0.02 & 0.01 & nd & nd & nd & nd & nd & nd & nd & nd \\
\hline 662049 & 0.40 & nd & nd & nd & nd & nd & nd & nd & nd & nd & nd & nd \\
\hline 662050 & 0.96 & 0.01 & 0.01 & nd & nd & nd & nd & nd & nd & nd & nd & nd \\
\hline 662051 & 1.03 & 0.02 & 0.02 & bdl & nd & nd & nd & nd & nd & nd & nd & nd \\
\hline 662052 & 0.66 & 0.02 & 0.02 & nd & nd & nd & nd & nd & nd & nd & nd & nd \\
\hline 662053 & 15.80 & 0.07 & 0.04 & 0.03 & nd & nd & nd & nd & nd & nd & nd & nd \\
\hline 662054 & 0.29 & 0.01 & 0.01 & nd & nd & nd & nd & nd & nd & nd & nd & nd \\
\hline 662055 & 0.81 & 0.03 & 0.03 & nd & nd & nd & nd & nd & nd & nd & nd & nd \\
\hline 662056 & 0.46 & 0.00 & bdl & bdl & nd & nd & nd & nd & nd & nd & nd & nd \\
\hline 662057 & 14.16 & 0.06 & 0.02 & 0.04 & nd & nd & nd & nd & nd & nd & nd & nd \\
\hline 662058 & 0.74 & 0.00 & bdl & bdl & nd & nd & nd & nd & nd & nd & nd & nd \\
\hline 662059 & 1.34 & 0.02 & 0.02 & nd & nd & nd & nd & nd & nd & nd & nd & nd \\
\hline 662060 & 0.79 & 0.01 & nd & 0.01 & nd & bdl & nd & nd & nd & nd & nd & nd \\
\hline 662061 & 0.21 & 0.01 & 0.01 & nd & nd & nd & nd & nd & nd & nd & nd & nd \\
\hline 662062 & 0.17 & 0.02 & 0.02 & nd & nd & nd & nd & nd & nd & nd & nd & nd \\
\hline 662063 & 0.17 & 0.02 & 0.02 & nd & nd & nd & nd & nd & nd & nd & nd & nd \\
\hline 662064 & 0.43 & 0.02 & 0.02 & nd & nd & nd & nd & nd & nd & nd & nd & nd \\
\hline 662065 & 1.38 & 0.01 & 0.01 & nd & nd & nd & nd & nd & nd & nd & nd & nd \\
\hline 662066 & 0.21 & 0.04 & bdl & nd & bdl & 0.02 & 0.02 & nd & nd & nd & nd & 0.01 \\
\hline 662067 & 1.57 & 0.01 & 0.01 & nd & nd & nd & nd & nd & nd & nd & nd & nd \\
\hline 662068 & 0.35 & 0.02 & 0.02 & nd & nd & bdl & nd & nd & nd & nd & nd & 0.00 \\
\hline 662069 & 0.29 & 0.02 & 0.02 & nd & nd & nd & nd & nd & nd & nd & nd & nd \\
\hline 662070 & 10.47 & 0.02 & 0.02 & nd & nd & nd & nd & nd & nd & nd & nd & nd \\
\hline 662071 & 0.66 & 0.01 & bdl & 0.01 & nd & nd & nd & nd & nd & nd & nd & nd \\
\hline \multicolumn{13}{|c|}{ Trip Blanks } \\
\hline 662072 & 0.04 & nd & nd & nd & nd & nd & nd & nd & nd & nd & nd & nd \\
\hline 662073 & 0.03 & nd & nd & nd & nd & nd & nd & nd & nd & nd & nd & nd \\
\hline 662074 & 0.10 & nd & nd & nd & nd & nd & nd & nd & nd & nd & nd & nd \\
\hline 662075 & 0.02 & nd & nd & nd & nd & nd & nd & nd & nd & nd & nd & nd \\
\hline
\end{tabular}


Table 1. Mass of volatile organic compounds detected in soil-gas samplers deployed on June 29, 2011, collected from the 8th Street site, Fort Gordon, Georgia.-Continued.

[MDL, method detection level; TPH, total petroleum hydrocarbons; $\mu \mathrm{g}$, micrograms; BTEX, benzene, toluene, ethylbenzene, and xylenes; ---, not applicable; m, meta; p, para; o, ortho; $\mathrm{C}_{11}, \mathrm{C}_{13}$, and $\mathrm{C}_{15}$, undecane, tridecane, and pentadecane; $c$, cis; $t$, trans; DCE, dichloroethylene; MTBE, methyl tert-butyl ether; DCA, dichloroethane; TCA, trichloroethane; TCE, trichloroethylene; PCE, perchloroethylene; DCB, dichlorobenzene; $\mathrm{CCl}_{4}$, carbon tetrachloride; nd, not detected; bdl, below detection level]

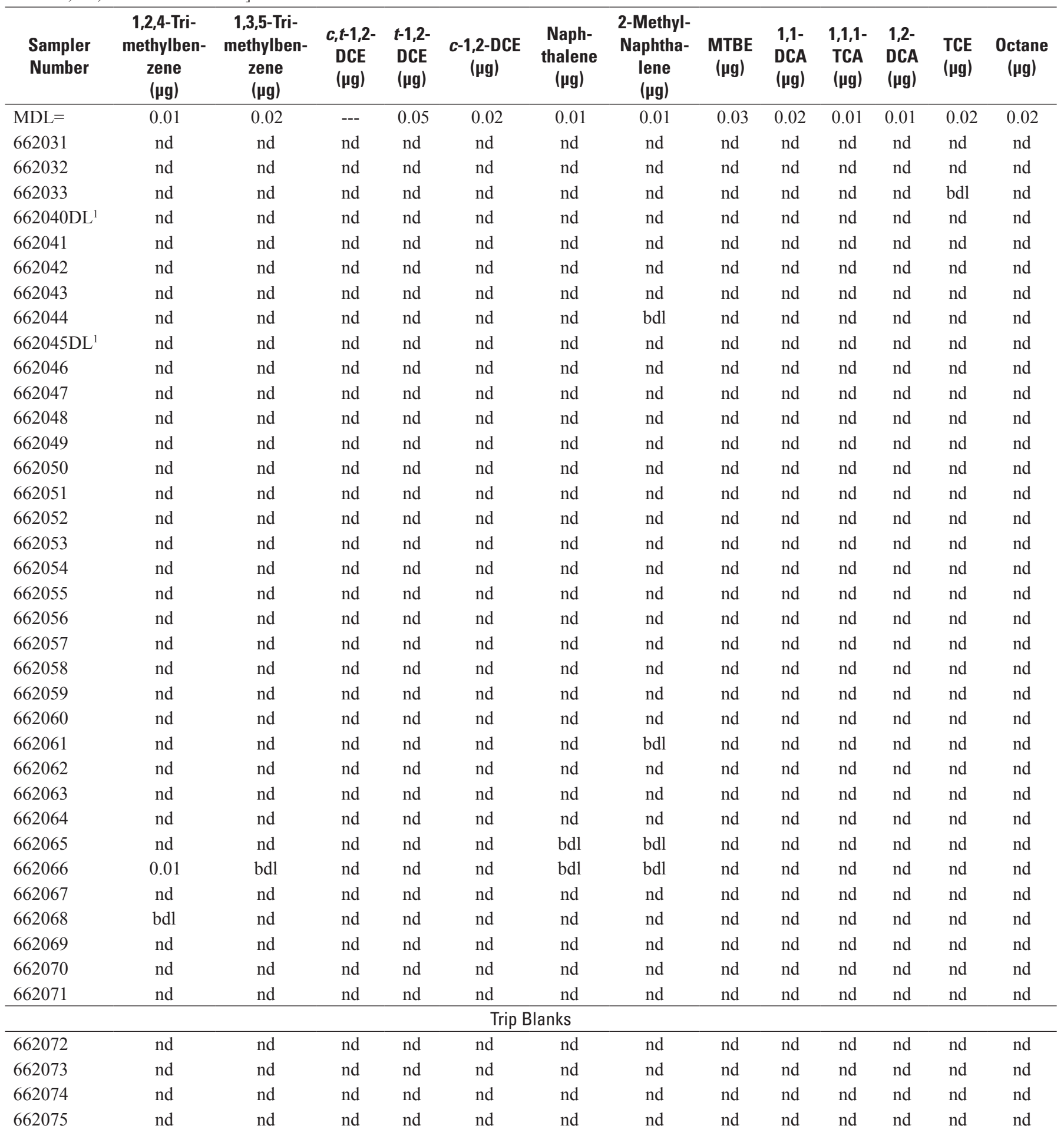


Table 1. Mass of volatile organic compounds detected in soil-gas samplers deployed on June 29, 2011, collected from the 8th Street site, Fort Gordon, Georgia-Continued.

[MDL, method detection level; TPH, total petroleum hydrocarbons; $\mu \mathrm{g}$, micrograms; BTEX, benzene, toluene, ethylbenzene, and xylenes; ---, not applicable; $m$, meta; $p$, para; o, ortho; $\mathrm{C}_{11}, \mathrm{C}_{13}$, and $\mathrm{C}_{15}$, undecane, tridecane, and pentadecane; $c$, cis; $t$, trans; DCE, dichloroethylene; MTBE, methyl tert-butyl ether; DCA, dichloroethane; TCA, trichloroethane; TCE, trichloroethylene; PCE, perchloroethylene; $\mathrm{DCB}$, dichlorobenzene; $\mathrm{CCl}_{4}$, carbon tetrachloride; nd, not detected; bdl, below detection level]

\begin{tabular}{|c|c|c|c|c|c|c|c|c|c|c|}
\hline $\begin{array}{l}\text { Sampler } \\
\text { Number }\end{array}$ & $\begin{array}{l}\text { PCE } \\
(\mu \mathrm{g})\end{array}$ & $\begin{array}{l}1-4- \\
\text { DCB } \\
(\mu \mathrm{g})\end{array}$ & $\begin{array}{l}\text { Chlo- } \\
\text { roform } \\
(\mu g)\end{array}$ & $\begin{array}{l}\mathrm{CCl}_{4} \\
(\mu \mathrm{g})\end{array}$ & $\begin{array}{l}1,1,2- \\
\text { TCA } \\
(\mu g)\end{array}$ & $\begin{array}{c}\text { Chloro- } \\
\text { benzene } \\
\text { ( } \mu \mathrm{g})\end{array}$ & $\begin{array}{c}\text { 1,1,1,2-Tetra- } \\
\text { chloroethane } \\
(\mu \mathrm{g})\end{array}$ & $\begin{array}{c}\text { 1,1,2,2-Tetra- } \\
\text { chloroethane } \\
(\mu \mathrm{g})\end{array}$ & $\begin{array}{c}\text { 1,3-Dichlo- } \\
\text { robenzene } \\
(\mu \mathrm{g})\end{array}$ & $\begin{array}{c}\text { 1,2-Dichlo- } \\
\text { robenzene } \\
(\mu \mathrm{g})\end{array}$ \\
\hline $\mathrm{MDL}=$ & 0.02 & 0.01 & 0.01 & 0.03 & 0.02 & 0.03 & 0.02 & 0.01 & 0.01 & 0.01 \\
\hline 662031 & nd & nd & 0.10 & nd & nd & nd & nd & nd & nd & nd \\
\hline 662032 & nd & nd & nd & nd & nd & nd & nd & nd & nd & nd \\
\hline 662033 & 0.04 & nd & nd & nd & nd & nd & nd & nd & nd & nd \\
\hline $662040 \mathrm{DL}^{1}$ & nd & nd & 0.23 & nd & nd & nd & nd & nd & nd & nd \\
\hline 662041 & nd & nd & 0.13 & nd & nd & nd & nd & nd & nd & nd \\
\hline 662042 & nd & nd & nd & nd & nd & nd & nd & nd & nd & nd \\
\hline 662043 & nd & nd & 0.03 & nd & nd & nd & nd & nd & nd & nd \\
\hline 662044 & nd & nd & nd & nd & nd & nd & nd & nd & nd & nd \\
\hline $662045 \mathrm{DL}^{1}$ & nd & nd & nd & nd & nd & nd & nd & nd & nd & nd \\
\hline 662046 & nd & nd & 0.03 & nd & nd & nd & nd & nd & nd & nd \\
\hline 662047 & nd & nd & nd & nd & nd & nd & nd & nd & nd & nd \\
\hline 662048 & nd & nd & 0.02 & nd & nd & nd & nd & nd & nd & nd \\
\hline 662049 & nd & nd & nd & nd & nd & nd & nd & nd & nd & nd \\
\hline 662050 & nd & nd & nd & nd & nd & nd & nd & nd & nd & nd \\
\hline 662051 & nd & nd & nd & nd & nd & nd & nd & nd & nd & nd \\
\hline 662052 & nd & nd & nd & nd & nd & nd & nd & nd & nd & nd \\
\hline 662053 & nd & nd & 0.01 & nd & nd & nd & nd & nd & nd & nd \\
\hline 662054 & nd & nd & nd & nd & nd & nd & nd & nd & nd & nd \\
\hline 662055 & bdl & nd & nd & nd & nd & nd & nd & nd & nd & nd \\
\hline 662056 & nd & nd & nd & nd & nd & nd & nd & nd & nd & nd \\
\hline 662057 & nd & nd & nd & nd & nd & nd & nd & nd & nd & nd \\
\hline 662058 & nd & nd & nd & nd & nd & nd & nd & nd & nd & nd \\
\hline 662059 & bdl & nd & nd & nd & nd & nd & nd & nd & nd & nd \\
\hline 662060 & nd & nd & nd & nd & nd & nd & nd & nd & nd & nd \\
\hline 662061 & nd & nd & nd & nd & nd & nd & nd & nd & nd & nd \\
\hline 662062 & nd & nd & nd & nd & nd & nd & nd & nd & nd & nd \\
\hline 662063 & nd & nd & nd & nd & nd & nd & nd & nd & nd & nd \\
\hline 662064 & nd & nd & nd & nd & nd & nd & nd & nd & nd & nd \\
\hline 662065 & bdl & nd & nd & nd & nd & nd & nd & nd & nd & nd \\
\hline 662066 & nd & nd & nd & nd & nd & nd & nd & nd & nd & nd \\
\hline 662067 & nd & nd & 0.01 & nd & nd & nd & nd & nd & nd & nd \\
\hline 662068 & nd & nd & nd & nd & nd & nd & nd & nd & nd & nd \\
\hline 662069 & nd & nd & nd & nd & nd & nd & nd & nd & nd & nd \\
\hline 662070 & nd & nd & nd & nd & nd & nd & nd & nd & nd & nd \\
\hline 662071 & nd & nd & nd & nd & nd & nd & nd & nd & nd & nd \\
\hline \multicolumn{11}{|c|}{ Trip Blanks } \\
\hline 662072 & nd & nd & nd & nd & nd & nd & nd & nd & nd & nd \\
\hline 662073 & nd & nd & nd & nd & nd & nd & nd & nd & nd & nd \\
\hline 662074 & nd & nd & nd & nd & nd & nd & nd & nd & nd & nd \\
\hline 662075 & nd & nd & nd & nd & nd & nd & nd & nd & nd & nd \\
\hline
\end{tabular}

${ }^{1}$ Levels of volatile organic compounds in the vapor phase of the soil-gas sampler, as detected by a photoionization detector, exceeded the maximum analytical limit of gas chromotograph and were diluted by a factor of 10 prior to analysis. The MDLs of all diluted samples are a factor of 10 greater than the MDLs of undiluted samples. 
Table 2. Mass of volatile organic compounds detected in soil-gas samplers deployed on August 8, 2011, collected from the 8th Street site, Fort Gordon, Georgia.

[MDL, method detection level; TPH, total petroleum hydrocarbons; $\mu \mathrm{g}$, micrograms; BTEX, benzene, toluene, ethylbenzene, and xylenes; ---, not applicable; $m$, meta; , para; $o$, ortho; $\mathrm{C}_{11}, \mathrm{C}_{13}$, and $\mathrm{C}_{15}$, undecane, tridecane, and pentadecane; $c$, cis; $t$, trans; DCE, dichloroethylene; MTBE, methyl tert-butyl ether; DCA, dichloroethane; TCA, trichloroethane; TCE, trichloroethylene; PCE, perchloroethylene; DCB, dichlorobenzene; $\mathrm{CCl}_{4}$, carbon tetrachloride; nd, not detected; bdl, below detection level]

\begin{tabular}{|c|c|c|c|c|c|c|c|c|c|c|c|c|}
\hline $\begin{array}{l}\text { Sampler } \\
\text { Number }\end{array}$ & $\begin{array}{l}\text { TPH } \\
\text { ( } \mu g)\end{array}$ & $\begin{array}{c}\text { BTEX } \\
(\mu g)\end{array}$ & $\begin{array}{c}\text { Benzene } \\
(\mu \mathrm{g})\end{array}$ & $\begin{array}{c}\text { Toluene } \\
\text { ( } \mu \mathrm{g})\end{array}$ & $\begin{array}{c}\text { Ethyl- } \\
\text { benzene } \\
(\mu \mathrm{g})\end{array}$ & $\begin{array}{c}m-, p- \\
\text { Xylene } \\
(\mu g)\end{array}$ & $\begin{array}{c}\text { o-Xylene } \\
\text { ( } \mu \mathrm{g})\end{array}$ & $\begin{array}{c}C_{11^{\prime}} C_{13^{\prime}} \\
\& C_{15} \\
(\mu g)\end{array}$ & $\begin{array}{c}\text { Undec- } \\
\text { ane } \\
(\mu \mathrm{g})\end{array}$ & $\begin{array}{l}\text { Tridec- } \\
\text { ane } \\
(\mu \mathrm{g})\end{array}$ & $\begin{array}{l}\text { Penta- } \\
\text { decane } \\
(\mu g)\end{array}$ & $\begin{array}{c}\text { Trimethyl- } \\
\text { benzene } \\
(\mu \mathrm{g})\end{array}$ \\
\hline $\mathrm{MDL}=$ & 0.02 & --- & 0.01 & 0.01 & 0.02 & 0.02 & 0.01 & --- & 0.01 & 0.01 & 0.01 & --- \\
\hline 662331 & 5.92 & nd & nd & nd & nd & nd & nd & 0.01 & 0.01 & nd & nd & nd \\
\hline 662332 & 10.22 & nd & nd & nd & nd & nd & nd & nd & nd & nd & nd & nd \\
\hline 662333 & 1.06 & nd & nd & nd & nd & nd & nd & nd & nd & nd & nd & nd \\
\hline 662334 & 0.04 & nd & nd & nd & nd & nd & nd & nd & nd & nd & nd & nd \\
\hline 662335 & 0.68 & nd & nd & nd & nd & nd & nd & nd & nd & nd & nd & nd \\
\hline 662336 & 24.73 & 0.11 & nd & 0.11 & nd & nd & nd & bdl & nd & nd & bdl & nd \\
\hline 662337 & 0.07 & nd & nd & nd & nd & nd & nd & nd & nd & nd & nd & nd \\
\hline 662338 & 0.85 & nd & nd & nd & nd & nd & nd & nd & nd & nd & nd & nd \\
\hline 662339 & 11.82 & nd & nd & nd & nd & nd & nd & nd & nd & nd & nd & nd \\
\hline 662340 & 3.07 & nd & nd & nd & nd & nd & nd & nd & nd & nd & nd & nd \\
\hline 662341 & 0.64 & nd & nd & nd & nd & nd & nd & 0.01 & 0.01 & nd & nd & nd \\
\hline 662342 & 0.84 & nd & nd & nd & nd & nd & nd & nd & nd & nd & nd & nd \\
\hline 662343 & 0.46 & nd & nd & nd & nd & nd & nd & nd & nd & nd & nd & nd \\
\hline 662344 & bdl & nd & nd & nd & nd & nd & nd & nd & nd & nd & nd & nd \\
\hline 662345 & 0.16 & nd & nd & nd & nd & nd & nd & nd & nd & nd & nd & nd \\
\hline 662346 & 0.86 & nd & nd & nd & nd & nd & nd & 0.72 & 0.71 & 0.01 & bdl & nd \\
\hline 662347 & 8.63 & nd & nd & nd & nd & nd & nd & 6.59 & 5.98 & 0.19 & 0.42 & nd \\
\hline 662348 & 0.31 & nd & nd & nd & nd & nd & nd & nd & nd & nd & nd & nd \\
\hline 662349 & 0.62 & nd & nd & nd & nd & nd & nd & nd & nd & nd & nd & nd \\
\hline 662350 & 1.68 & nd & nd & nd & nd & nd & nd & 1.29 & 1.20 & 0.03 & 0.07 & nd \\
\hline \multicolumn{13}{|c|}{ Trip Blanks } \\
\hline 662351 & bdl & nd & nd & nd & nd & nd & nd & nd & nd & nd & nd & nd \\
\hline 662352 & nd & nd & nd & nd & nd & nd & nd & nd & nd & nd & nd & nd \\
\hline
\end{tabular}


Table 2. Mass of volatile organic compounds detected in soil-gas samplers deployed on June 29, 2011, collected from the 8th Street site, Fort Gordon, Georgia.-Continued.

[MDL, method detection level; TPH, total petroleum hydrocarbons; $\mu \mathrm{g}$, micrograms; BTEX, benzene, toluene, ethylbenzene, and xylenes; ---, not applicable; $m$, meta; $p$, para; o, ortho; $\mathrm{C}_{11}, \mathrm{C}_{13}$, and $\mathrm{C}_{15}$, undecane, tridecane, and pentadecane; $c$, cis; $t$, trans; DCE, dichloroethylene; MTBE, methyl tert-butyl ether; DCA, dichloroethane; TCA, trichloroethane; TCE, trichloroethylene; PCE, perchloroethylene; DCB, dichlorobenzene; $\mathrm{CCl}_{4}$, carbon tetrachloride; nd, not detected; bdl, below detection level]

\begin{tabular}{|c|c|c|c|c|c|c|c|c|c|c|c|c|c|}
\hline $\begin{array}{l}\text { Sampler } \\
\text { Number }\end{array}$ & $\begin{array}{l}\text { 1,2,4-Tri- } \\
\text { methylben- } \\
\text { zene } \\
(\mu \mathrm{g})\end{array}$ & $\begin{array}{l}\text { 1,3,5-Tri- } \\
\text { methylben- } \\
\text { zene } \\
(\mu \mathrm{g})\end{array}$ & $\begin{array}{c}c, t-1,2- \\
\text { DCE } \\
(\mu g)\end{array}$ & $\begin{array}{l}t-1,2- \\
\text { DCE } \\
(\mu g)\end{array}$ & $\begin{array}{c}c-1,2-D C E \\
(\mu \mathrm{g})\end{array}$ & $\begin{array}{c}\text { Naph- } \\
\text { thalene } \\
\text { ( } \mu g)\end{array}$ & $\begin{array}{l}\text { 2-Methyl- } \\
\text { Naphtha- } \\
\text { lene } \\
(\mu \mathrm{g})\end{array}$ & $\begin{array}{c}\text { MTBE } \\
(\mu g)\end{array}$ & $\begin{array}{l}1,1- \\
\text { DCA } \\
(\mu g)\end{array}$ & $\begin{array}{l}1,1,1- \\
\text { TCA } \\
(\mu g)\end{array}$ & $\begin{array}{l}1,2- \\
D C A \\
(\mu g)\end{array}$ & $\begin{array}{l}\text { TCE } \\
(\mu g)\end{array}$ & $\begin{array}{c}\text { Octane } \\
(\mu \mathrm{g})\end{array}$ \\
\hline 662331 & nd & nd & nd & nd & nd & nd & nd & nd & nd & nd & nd & nd & nd \\
\hline 662332 & nd & nd & nd & nd & nd & nd & nd & nd & nd & nd & nd & nd & nd \\
\hline 662335 & nd & nd & nd & nd & nd & nd & nd & nd & nd & nd & nd & nd & nd \\
\hline 662336 & nd & nd & nd & nd & nd & nd & nd & nd & nd & nd & nd & nd & nd \\
\hline 662337 & nd & nd & nd & nd & nd & nd & nd & nd & nd & nd & nd & nd & nd \\
\hline 662338 & nd & nd & nd & nd & nd & nd & nd & nd & nd & nd & nd & nd & nd \\
\hline 662339 & nd & nd & nd & nd & nd & nd & nd & nd & nd & nd & nd & nd & nd \\
\hline 662343 & nd & nd & nd & nd & nd & nd & nd & nd & nd & nd & nd & nd & nd \\
\hline 662344 & nd & nd & nd & nd & nd & nd & nd & nd & nd & nd & nd & nd & nd \\
\hline 662345 & nd & nd & nd & nd & nd & nd & nd & nd & nd & nd & nd & nd & nd \\
\hline 662346 & nd & nd & nd & nd & nd & nd & nd & nd & nd & nd & nd & nd & nd \\
\hline 662347 & nd & nd & nd & nd & nd & nd & nd & nd & nd & nd & nd & nd & nd \\
\hline 662348 & nd & nd & nd & nd & nd & nd & nd & nd & nd & nd & nd & nd & nd \\
\hline 662349 & nd & nd & nd & nd & nd & nd & nd & nd & nd & nd & nd & nd & nd \\
\hline 662350 & nd & nd & nd & nd & nd & nd & nd & nd & nd & nd & nd & nd & nd \\
\hline \multicolumn{14}{|c|}{ Trip Blanks } \\
\hline 662072 & nd & nd & nd & nd & nd & nd & nd & nd & nd & nd & nd & nd & nd \\
\hline
\end{tabular}


Table 2. Mass of volatile organic compounds detected in soil-gas samplers deployed on August 8, 2011, collected from the 8th Street site, Fort Gordon, Georgia-Continued.

[MDL, method detection level; TPH, total petroleum hydrocarbons; $\mu \mathrm{g}$, micrograms; BTEX, benzene, toluene, ethylbenzene, and xylenes; ---, not applicable; $m$, meta; $p$, para; o, ortho; $\mathrm{C}_{11}, \mathrm{C}_{13}$, and $\mathrm{C}_{15}$, undecane, tridecane, and pentadecane; $c$, cis; $t$, trans; DCE, dichloroethylene; MTBE, methyl tert-butyl ether; DCA, dichloroethane; TCA, trichloroethane; TCE, trichloroethylene; PCE, perchloroethylene; $\mathrm{DCB}$, dichlorobenzene; $\mathrm{CCl}_{4}$, carbon tetrachloride; nd, not detected; bdl, below detection level]

\begin{tabular}{|c|c|c|c|c|c|c|c|c|c|c|}
\hline $\begin{array}{l}\text { Sampler } \\
\text { Number }\end{array}$ & $\begin{array}{l}\text { PCE } \\
(\mu g)\end{array}$ & $\begin{array}{l}1-4- \\
\text { DCB } \\
(\mu g)\end{array}$ & $\begin{array}{c}\text { Chloro- } \\
\text { form } \\
(\mu \mathrm{g})\end{array}$ & $\begin{array}{l}\mathrm{CCl}_{4} \\
(\mu \mathrm{g})\end{array}$ & $\begin{array}{l}1,1,2- \\
\text { TCA } \\
(\mu g)\end{array}$ & $\begin{array}{c}\text { Chloro- } \\
\text { benzene } \\
(\mu \mathrm{g})\end{array}$ & $\begin{array}{c}\text { 1,1,1,2-Tetra- } \\
\text { chloroethane } \\
(\mu \mathrm{g})\end{array}$ & $\begin{array}{c}\text { 1,1,2,2-Tetra- } \\
\text { chloroethane } \\
(\mu \mathrm{g})\end{array}$ & $\begin{array}{l}\text { 1,3-Dichloro- } \\
\text { benzene } \\
(\mu \mathrm{g})\end{array}$ & $\begin{array}{l}\text { 1,2-Dichloro- } \\
\text { benzene } \\
(\mu \mathrm{g})\end{array}$ \\
\hline $\mathrm{MDL}=$ & 0.02 & 0.01 & 0.01 & 0.03 & 0.02 & 0.03 & 0.02 & 0.01 & 0.01 & 0.01 \\
\hline 662331 & nd & nd & 0.06 & nd & nd & nd & nd & nd & nd & nd \\
\hline 662332 & nd & nd & 0.03 & nd & nd & nd & nd & nd & nd & nd \\
\hline 662333 & nd & nd & nd & nd & nd & nd & nd & nd & nd & nd \\
\hline 662334 & nd & nd & nd & nd & nd & nd & nd & nd & nd & nd \\
\hline 662335 & nd & nd & nd & nd & nd & nd & nd & nd & nd & nd \\
\hline 662336 & nd & nd & nd & nd & nd & nd & nd & nd & nd & nd \\
\hline 662337 & nd & nd & nd & nd & nd & nd & nd & nd & nd & nd \\
\hline 662338 & nd & nd & nd & nd & nd & nd & nd & nd & nd & nd \\
\hline 662339 & nd & nd & 0.06 & nd & nd & nd & nd & nd & nd & nd \\
\hline 662340 & nd & nd & 0.28 & nd & nd & nd & nd & nd & nd & nd \\
\hline 662341 & nd & nd & nd & nd & nd & nd & nd & nd & nd & nd \\
\hline 662342 & nd & nd & nd & nd & nd & nd & nd & nd & nd & nd \\
\hline 662343 & nd & nd & nd & nd & nd & nd & nd & nd & nd & nd \\
\hline 662344 & nd & nd & nd & nd & nd & nd & nd & nd & nd & nd \\
\hline 662345 & nd & nd & nd & nd & nd & nd & nd & nd & nd & nd \\
\hline 662346 & nd & nd & nd & nd & nd & nd & nd & nd & nd & nd \\
\hline 662347 & nd & nd & nd & nd & nd & nd & nd & nd & nd & nd \\
\hline 662348 & nd & nd & nd & nd & nd & nd & nd & nd & nd & nd \\
\hline 662349 & nd & nd & nd & nd & nd & nd & nd & nd & nd & nd \\
\hline 662350 & nd & nd & nd & nd & nd & nd & nd & nd & nd & nd \\
\hline \multicolumn{11}{|c|}{ Trip Blanks } \\
\hline 662072 & nd & nd & nd & nd & nd & nd & nd & nd & nd & nd \\
\hline 662073 & nd & nd & nd & nd & nd & nd & nd & nd & nd & nd \\
\hline
\end{tabular}


Table 3. Mass of volatile organic compounds detected in soil-gas samplers deployed on July 7, 2011, collected from the Chamberlain Avenue site, Fort Gordon, Georgia.

[MDL, method detection level; TPH, total petroleum hydrocarbons; $\mu \mathrm{g}$, micrograms; BTEX, benzene, toluene, ethylbenzene, and xylenes; ---, not applicable; m, meta; p, para; o, ortho; $\mathrm{C}_{11}, \mathrm{C}_{13}$, and $\mathrm{C}_{15}$, undecane, tridecane, and pentadecane; $c$, cis; $t$, trans; DCE, dichloroethylene; MTBE, methyl tert-butyl ether; DCA, dichloroethane; TCA, trichloroethane; TCE, trichloroethylene; PCE, perchloroethylene; DCB, dichlorobenzene; $\mathrm{CCl}_{4}$, carbon tetrachloride; nd, not detected; bdl, below detection level]

\begin{tabular}{|c|c|c|c|c|c|c|c|c|c|c|c|c|}
\hline $\begin{array}{l}\text { Sampler } \\
\text { Number }\end{array}$ & $\begin{array}{l}\text { TPH } \\
\text { ( } \mu g)\end{array}$ & $\begin{array}{c}\text { BTEX } \\
(\mu \mathrm{g})\end{array}$ & $\begin{array}{c}\text { Benzene } \\
(\mu \mathrm{g})\end{array}$ & $\begin{array}{c}\text { Toluene } \\
\text { ( } \mu \mathrm{g})\end{array}$ & $\begin{array}{c}\text { Ethyl- } \\
\text { benzene } \\
(\mu \mathrm{g})\end{array}$ & $\begin{array}{c}m-, p- \\
\text { Xylene } \\
(\mu g)\end{array}$ & $\begin{array}{c}\text { o-Xylene } \\
\text { ( } \mu \mathrm{g})\end{array}$ & $\begin{array}{c}C_{11^{\prime}} C_{13^{\prime}} \\
\& C_{15} \\
(\mu g)\end{array}$ & $\begin{array}{l}\text { Undec- } \\
\text { ane } \\
(\mu \mathrm{g})\end{array}$ & $\begin{array}{c}\text { Tridec- } \\
\text { ane } \\
(\mu g)\end{array}$ & $\begin{array}{c}\text { Penta- } \\
\text { decane } \\
(\mu \mathrm{g})\end{array}$ & $\begin{array}{c}\text { Trimethyl- } \\
\text { benzene } \\
(\mu \mathrm{g})\end{array}$ \\
\hline $\mathrm{MDL}=$ & 0.02 & --- & 0.01 & 0.01 & 0.02 & 0.02 & 0.01 & --- & 0.01 & 0.01 & 0.01 & --- \\
\hline 662293 & 6.93 & nd & nd & nd & nd & nd & nd & nd & nd & nd & nd & nd \\
\hline 662294 & 2.20 & nd & nd & nd & nd & nd & nd & nd & nd & nd & nd & nd \\
\hline 662295 & 0.87 & 0.13 & nd & 0.13 & nd & nd & nd & nd & nd & nd & nd & nd \\
\hline 662296 & 6.25 & 0.08 & 0.04 & 0.04 & nd & nd & nd & 0.07 & 0.03 & 0.04 & nd & nd \\
\hline 662297 & 30.81 & nd & nd & nd & nd & nd & nd & 0.76 & 0.11 & 0.46 & 0.19 & nd \\
\hline 662298 & 36.37 & 0.21 & 0.02 & 0.19 & nd & nd & nd & 1.51 & 0.07 & 0.95 & 0.49 & nd \\
\hline 662299 & 6.42 & nd & nd & nd & nd & nd & nd & nd & nd & nd & nd & nd \\
\hline 662300 & 426.36 & 0.03 & 0.03 & nd & nd & nd & nd & 30.97 & 1.67 & 13.27 & 16.02 & 0.00 \\
\hline 662301 & 59.92 & 0.02 & nd & 0.02 & nd & nd & nd & 1.89 & 0.25 & 0.79 & 0.85 & nd \\
\hline 662302 & 4.35 & 0.05 & 0.05 & nd & nd & nd & nd & 0.08 & 0.05 & 0.03 & nd & nd \\
\hline 662303 & 1.96 & 0.03 & 0.03 & nd & nd & nd & nd & 0.10 & 0.03 & 0.05 & 0.01 & nd \\
\hline 662304 & 230.07 & 0.06 & nd & 0.06 & nd & nd & nd & 15.85 & 0.45 & 5.59 & 9.81 & nd \\
\hline 662305 & 340.33 & 0.06 & nd & 0.02 & nd & 0.02 & 0.02 & 29.80 & 0.94 & 11.40 & 17.46 & 0.07 \\
\hline 662306 & 2.53 & nd & nd & nd & nd & nd & nd & 0.01 & 0.01 & nd & nd & nd \\
\hline 662307 & 102.17 & 0.02 & nd & 0.02 & nd & nd & nd & 6.46 & 0.68 & 2.39 & 3.39 & 0.09 \\
\hline 662308 & 421.69 & 0.73 & nd & 0.31 & 0.05 & 0.24 & 0.13 & 28.65 & 5.80 & 12.00 & 10.85 & 1.11 \\
\hline 662309 & 356.36 & 0.22 & nd & 0.17 & nd & 0.03 & 0.02 & 27.76 & 6.29 & 12.46 & 9.01 & 0.08 \\
\hline 662310 & 195.20 & 0.16 & 0.03 & 0.12 & nd & nd & nd & 8.19 & 0.84 & 3.87 & 3.48 & 0.00 \\
\hline 662311 & 2.75 & 0.07 & 0.03 & 0.04 & nd & nd & nd & 0.04 & 0.02 & nd & 0.02 & nd \\
\hline 662312 & 120.24 & 0.12 & nd & 0.05 & nd & 0.05 & 0.03 & 6.95 & 1.12 & 2.74 & 3.08 & 0.13 \\
\hline 662313 & 58.52 & 0.09 & nd & 0.06 & nd & 0.02 & 0.02 & 3.11 & 1.32 & 1.00 & 0.79 & 0.16 \\
\hline 662314 & 5.05 & nd & nd & nd & nd & nd & nd & 0.01 & 0.01 & nd & nd & nd \\
\hline 662315 & 7.07 & 0.06 & nd & 0.06 & nd & nd & nd & 0.03 & bdl & 0.03 & nd & nd \\
\hline 662316 & 3.22 & nd & nd & nd & nd & nd & nd & 0.11 & 0.03 & 0.06 & 0.03 & nd \\
\hline 662317 & 167.30 & 0.62 & nd & 0.34 & 0.05 & 0.16 & 0.07 & 8.56 & 3.78 & 3.78 & 1.00 & 0.75 \\
\hline 662318 & 26.82 & 0.43 & 0.05 & 0.28 & 0.02 & 0.05 & 0.03 & 0.18 & 0.18 & nd & nd & 0.05 \\
\hline 662319 & 1.86 & 0.08 & 0.05 & nd & nd & 0.02 & 0.01 & 0.03 & 0.03 & nd & nd & nd \\
\hline 662320 & 67.05 & 0.11 & 0.04 & nd & nd & 0.03 & 0.04 & 2.16 & 0.60 & 1.03 & 0.53 & 0.06 \\
\hline 662321 & 1.13 & nd & nd & nd & nd & nd & nd & nd & nd & nd & nd & nd \\
\hline 662322 & 10.06 & nd & nd & nd & nd & nd & nd & 0.05 & 0.03 & 0.02 & nd & 0.05 \\
\hline \multicolumn{13}{|c|}{ Trip Blanks } \\
\hline 662323 & bdl & nd & nd & nd & nd & nd & nd & nd & nd & nd & nd & nd \\
\hline 662328 & nd & nd & nd & nd & nd & nd & nd & nd & nd & nd & nd & nd \\
\hline 662329 & nd & nd & nd & nd & nd & nd & nd & nd & nd & nd & nd & nd \\
\hline 662330 & 0.02 & nd & nd & nd & nd & nd & nd & nd & nd & nd & nd & nd \\
\hline
\end{tabular}


Table 3. Mass of volatile organic compounds detected in soil-gas samplers deployed on July 7, 2011, collected from the Chamberlain Avenue site, Fort Gordon, Georgia.-Continued.

[MDL, method detection level; TPH, total petroleum hydrocarbons; $\mu \mathrm{g}$, micrograms; BTEX, benzene, toluene, ethylbenzene, and xylenes; ---, not applicable; $m$, meta; p, para; o, ortho; $\mathrm{C}_{11}, \mathrm{C}_{13}$, and $\mathrm{C}_{15}$, undecane, tridecane, and pentadecane; $c$, cis; $t$, trans; DCE, dichloroethylene; MTBE, methyl tert-butyl ether; DCA, dichloroethane; TCA, trichloroethane; TCE, trichloroethylene; PCE, perchloroethylene; DCB, dichlorobenzene; $\mathrm{CCl}_{4}$, carbon tetrachloride; nd, not detected; bdl, below detection level]

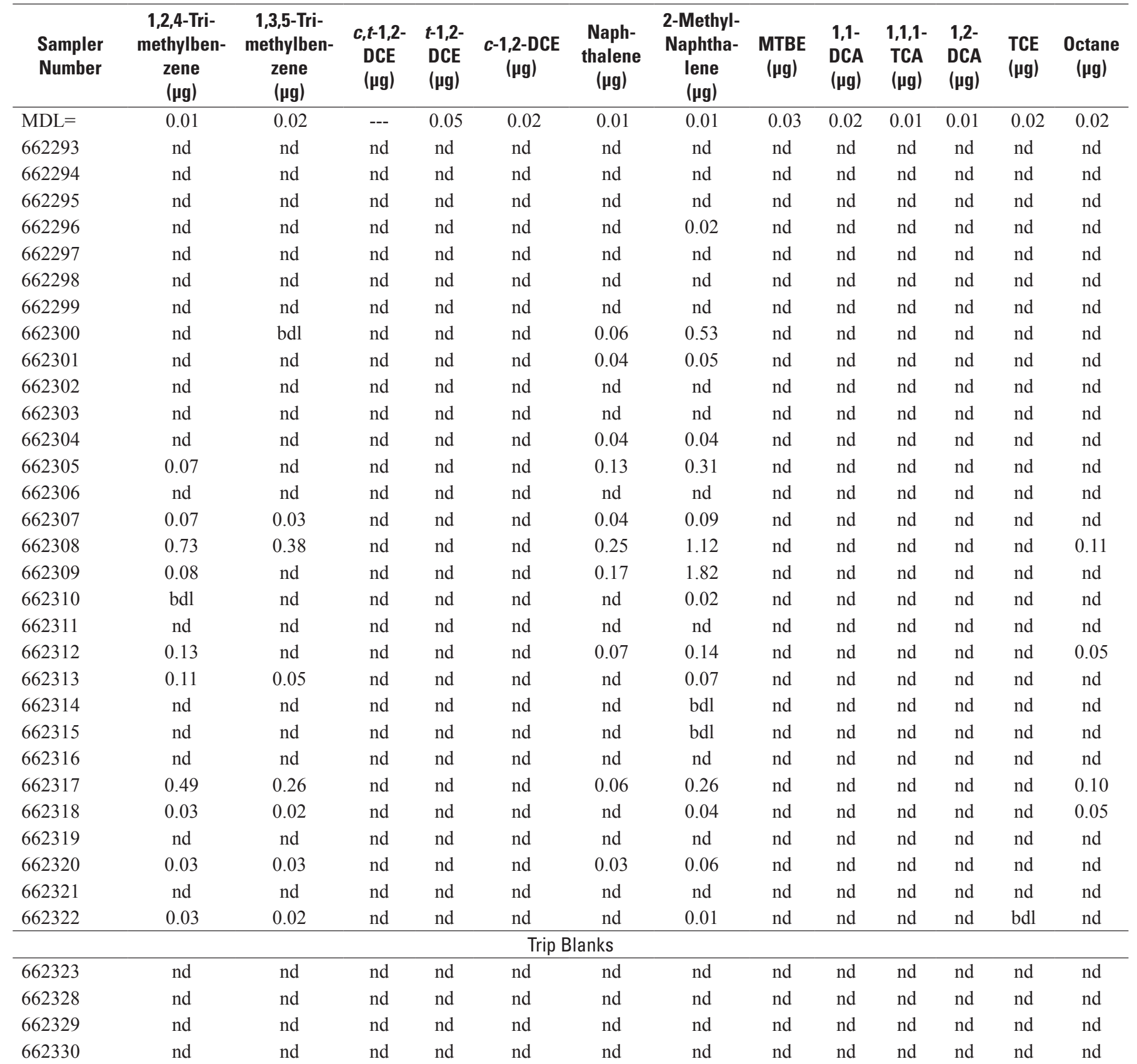


Table 3. Mass of volatile organic compounds detected in soil-gas samplers deployed on July 7, 2011, collected from the Chamberlain Avenue site, Fort Gordon, Georgia-Continued.

[MDL, method detection level; TPH, total petroleum hydrocarbons; $\mu \mathrm{g}$, micrograms; BTEX, benzene, toluene, ethylbenzene, and xylenes; ---, not applicable; $m$, meta; $p$, para; o, ortho; $\mathrm{C}_{11}, \mathrm{C}_{13}$, and $\mathrm{C}_{15}$, undecane, tridecane, and pentadecane; $c$, cis; $t$, trans; DCE, dichloroethylene; MTBE, methyl tert-butyl ether; DCA, dichloroethane; TCA, trichloroethane; TCE, trichloroethylene; PCE, perchloroethylene; $\mathrm{DCB}$, dichlorobenzene; $\mathrm{CCl}_{4}$, carbon tetrachloride; nd, not detected; bdl, below detection level]

\begin{tabular}{|c|c|c|c|c|c|c|c|c|c|c|}
\hline $\begin{array}{l}\text { Sampler } \\
\text { Number }\end{array}$ & $\begin{array}{l}\text { PCE } \\
(\mu g)\end{array}$ & $\begin{array}{l}1-4- \\
\text { DCB } \\
(\mu \mathrm{g})\end{array}$ & $\begin{array}{c}\text { Chloro- } \\
\text { form } \\
(\mu \mathrm{g})\end{array}$ & $\begin{array}{l}\mathrm{CCI}_{4} \\
(\mu \mathrm{g})\end{array}$ & $\begin{array}{l}1,1,2- \\
\text { TCA } \\
(\mu g)\end{array}$ & $\begin{array}{c}\text { Chloro- } \\
\text { benzene } \\
(\mu \mathrm{g})\end{array}$ & $\begin{array}{c}\text { 1,1,1,2-Tetra- } \\
\text { chloroethane } \\
(\mu \mathrm{g})\end{array}$ & $\begin{array}{c}\text { 1,1,2,2-Tetra- } \\
\text { chloroethane } \\
(\mu \mathrm{g})\end{array}$ & $\begin{array}{c}\text { 1,3-Dichloro- } \\
\text { benzene } \\
(\mu g)\end{array}$ & $\begin{array}{l}\text { 1,2-Dichloro- } \\
\text { benzene } \\
(\mu \mathrm{g})\end{array}$ \\
\hline $\mathrm{MDL}=$ & 0.02 & 0.01 & 0.01 & 0.03 & 0.02 & 0.03 & 0.02 & 0.01 & 0.01 & 0.01 \\
\hline 662293 & 0.23 & nd & nd & nd & nd & nd & nd & nd & nd & nd \\
\hline 662294 & 0.90 & nd & nd & nd & nd & nd & nd & nd & nd & nd \\
\hline 662295 & 0.03 & nd & nd & nd & nd & nd & nd & nd & nd & nd \\
\hline 662296 & nd & nd & nd & nd & nd & nd & nd & nd & nd & nd \\
\hline 662297 & 0.05 & nd & nd & nd & nd & nd & nd & nd & nd & nd \\
\hline 662298 & 0.07 & nd & nd & nd & nd & nd & nd & nd & nd & nd \\
\hline 662299 & 0.04 & nd & nd & nd & nd & nd & nd & nd & nd & nd \\
\hline 662300 & nd & nd & nd & nd & nd & nd & nd & nd & nd & nd \\
\hline 662301 & nd & nd & nd & nd & nd & nd & nd & nd & nd & nd \\
\hline 662302 & 0.06 & nd & nd & nd & nd & nd & nd & nd & nd & nd \\
\hline 662303 & 0.05 & nd & nd & nd & nd & nd & nd & nd & nd & nd \\
\hline 662304 & nd & nd & nd & nd & nd & nd & nd & nd & nd & nd \\
\hline 662305 & nd & nd & nd & nd & nd & nd & nd & nd & nd & nd \\
\hline 662306 & 0.06 & nd & nd & nd & nd & nd & nd & nd & nd & nd \\
\hline 662307 & 0.03 & nd & nd & nd & nd & nd & nd & nd & nd & nd \\
\hline 662308 & nd & nd & nd & nd & nd & nd & nd & nd & nd & nd \\
\hline 662309 & 0.10 & nd & nd & nd & nd & nd & nd & nd & nd & nd \\
\hline 662310 & nd & nd & nd & nd & nd & nd & nd & nd & nd & nd \\
\hline 662311 & 0.03 & nd & nd & nd & nd & nd & nd & nd & nd & nd \\
\hline 662312 & nd & nd & nd & nd & nd & nd & nd & nd & nd & nd \\
\hline 662313 & 0.07 & nd & nd & nd & nd & nd & nd & nd & nd & nd \\
\hline 662314 & 0.30 & nd & nd & nd & nd & nd & nd & nd & nd & nd \\
\hline 662315 & 0.08 & nd & nd & nd & nd & nd & nd & nd & nd & nd \\
\hline 662316 & 0.04 & nd & nd & nd & nd & nd & nd & nd & nd & nd \\
\hline 662317 & nd & nd & nd & nd & nd & nd & nd & nd & nd & nd \\
\hline 662318 & nd & nd & nd & nd & nd & nd & nd & nd & nd & nd \\
\hline 662319 & nd & nd & nd & nd & nd & nd & nd & nd & nd & nd \\
\hline 662320 & 0.04 & nd & nd & nd & nd & nd & nd & nd & nd & nd \\
\hline 662321 & 0.07 & nd & nd & nd & nd & nd & nd & nd & nd & nd \\
\hline 662322 & 0.05 & nd & nd & nd & nd & nd & nd & nd & nd & nd \\
\hline \multicolumn{11}{|c|}{ Trip Blanks } \\
\hline 662323 & nd & nd & nd & nd & nd & nd & nd & nd & nd & nd \\
\hline 662328 & nd & nd & nd & nd & nd & nd & nd & nd & nd & nd \\
\hline 662329 & nd & nd & nd & nd & nd & nd & nd & nd & nd & nd \\
\hline 662330 & nd & nd & nd & nd & nd & nd & nd & nd & nd & nd \\
\hline
\end{tabular}


Table 4. Mass of volatile organic compounds detected in soil-gas samplers deployed on July 18, 2011, collected from the 12th Street site, Fort Gordon, Georgia.

[MDL, method detection level; TPH, total petroleum hydrocarbons; $\mu \mathrm{g}$, micrograms; BTEX, benzene, toluene, ethylbenzene, and xylenes; ---, not applicable; $m$, meta; , para; $o$, ortho; $\mathrm{C}_{11}, \mathrm{C}_{13}$, and $\mathrm{C}_{15}$, undecane, tridecane, and pentadecane; $c$, cis; $t$, trans; DCE, dichloroethylene; MTBE, methyl tert-butyl ether; DCA, dichloroethane; TCA, trichloroethane; TCE, trichloroethylene; PCE, perchloroethylene; DCB, dichlorobenzene; $\mathrm{CCl}_{4}$, carbon tetrachloride; nd, not detected; bdl, below detection level]

\begin{tabular}{|c|c|c|c|c|c|c|c|c|c|c|c|c|}
\hline $\begin{array}{l}\text { Sampler } \\
\text { Number }\end{array}$ & $\begin{array}{l}\text { TPH } \\
(\mu g)\end{array}$ & $\begin{array}{c}\text { BTEX } \\
(\mu g)\end{array}$ & $\begin{array}{c}\text { Benzene } \\
\text { ( } \mu \mathrm{g})\end{array}$ & $\begin{array}{c}\text { Toluene } \\
\text { ( } \mu \mathrm{g})\end{array}$ & $\begin{array}{c}\text { Ethyl- } \\
\text { benzene } \\
(\mu \mathrm{g})\end{array}$ & $\begin{array}{c}\text { m-,p- } \\
\text { Xylene } \\
(\mu g)\end{array}$ & $\begin{array}{c}\text { o-Xylene } \\
\text { ( } \mu \mathrm{g})\end{array}$ & $\begin{array}{c}C_{11^{\prime}} C_{13^{\prime}} \\
\& C_{15} \\
(\mu g)\end{array}$ & $\begin{array}{c}\text { Undec- } \\
\text { ane } \\
(\mu g)\end{array}$ & $\begin{array}{c}\text { Tridec- } \\
\text { ane } \\
(\mu \mathrm{g})\end{array}$ & $\begin{array}{l}\text { Penta- } \\
\text { decane } \\
(\mu g)\end{array}$ & $\begin{array}{c}\text { Trimethyl- } \\
\text { benzene } \\
(\mu \mathrm{g})\end{array}$ \\
\hline $\mathrm{MDL}=$ & 0.02 & --- & 0.01 & 0.01 & 0.02 & 0.02 & 0.01 & --- & 0.01 & 0.01 & 0.01 & --- \\
\hline 662196 & 0.15 & nd & nd & nd & nd & nd & nd & nd & nd & nd & nd & nd \\
\hline 662197 & 5.94 & nd & nd & nd & nd & nd & nd & nd & nd & nd & nd & nd \\
\hline 662198 & 2.55 & nd & nd & nd & nd & nd & nd & nd & nd & nd & nd & nd \\
\hline 662199 & 14.36 & 0.00 & nd & nd & nd & bdl & nd & nd & nd & nd & nd & 0.02 \\
\hline 662200 & 24.37 & 0.03 & nd & 0.03 & nd & nd & nd & 0.02 & nd & nd & 0.02 & nd \\
\hline 662201 & 16.18 & 0.02 & nd & 0.02 & nd & nd & nd & nd & nd & nd & nd & nd \\
\hline 662202 & 0.19 & nd & nd & nd & nd & nd & nd & nd & nd & nd & nd & nd \\
\hline 662203 & 4.45 & nd & nd & nd & nd & nd & nd & 0.00 & nd & nd & bdl & nd \\
\hline 662204 & 0.97 & nd & nd & nd & nd & nd & nd & nd & nd & nd & nd & nd \\
\hline 662205 & 0.40 & nd & nd & nd & nd & nd & nd & nd & nd & nd & nd & nd \\
\hline 662206 & 7.18 & nd & nd & nd & nd & nd & nd & nd & nd & nd & nd & nd \\
\hline 662207 & 2.42 & nd & nd & nd & nd & nd & nd & nd & nd & nd & nd & nd \\
\hline 662208 & 1.78 & nd & nd & nd & nd & nd & nd & nd & nd & nd & nd & nd \\
\hline 662209 & 0.30 & nd & nd & nd & nd & nd & nd & nd & nd & nd & nd & nd \\
\hline 662210 & 6.82 & nd & nd & nd & nd & nd & nd & nd & nd & nd & nd & nd \\
\hline 662211 & 0.54 & nd & nd & nd & nd & nd & nd & nd & nd & nd & nd & nd \\
\hline 662212 & 0.34 & nd & nd & nd & nd & nd & nd & nd & nd & nd & nd & nd \\
\hline 662213 & 0.40 & nd & nd & nd & nd & nd & nd & nd & nd & nd & nd & nd \\
\hline 662214 & 3.45 & nd & nd & nd & nd & nd & nd & nd & nd & nd & nd & nd \\
\hline 662215 & 1.30 & nd & nd & nd & nd & nd & nd & 0.01 & nd & nd & 0.01 & nd \\
\hline 662216 & 0.56 & nd & nd & nd & nd & nd & nd & nd & nd & nd & nd & nd \\
\hline 662217 & 0.26 & nd & nd & nd & nd & nd & nd & nd & nd & nd & nd & nd \\
\hline 662218 & 0.58 & nd & nd & nd & nd & nd & nd & 0.01 & nd & 0.01 & nd & nd \\
\hline 662219 & 2.19 & nd & nd & nd & nd & nd & nd & nd & nd & nd & nd & nd \\
\hline 662220 & 1.02 & nd & nd & nd & nd & nd & nd & nd & nd & nd & nd & nd \\
\hline 662221 & 0.66 & nd & nd & nd & nd & nd & nd & nd & nd & nd & nd & nd \\
\hline 662222 & 0.60 & 0.72 & nd & 0.72 & nd & nd & nd & nd & nd & nd & nd & nd \\
\hline 662223 & 2.33 & nd & nd & nd & nd & nd & nd & 0.65 & 0.63 & 0.02 & nd & nd \\
\hline 662224 & 0.67 & nd & nd & nd & nd & nd & nd & nd & nd & nd & nd & nd \\
\hline 662225 & 0.59 & 0.00 & nd & nd & nd & bdl & nd & nd & nd & nd & nd & 0.03 \\
\hline 662226 & 0.43 & nd & nd & nd & nd & nd & nd & nd & nd & nd & nd & nd \\
\hline 662227 & 0.70 & nd & nd & nd & nd & nd & nd & nd & nd & nd & nd & nd \\
\hline 662228 & 0.60 & nd & nd & nd & nd & nd & nd & nd & nd & nd & nd & nd \\
\hline 662229 & 0.48 & nd & nd & nd & nd & nd & nd & nd & nd & nd & nd & nd \\
\hline 662230 & 0.62 & nd & nd & nd & nd & nd & nd & nd & nd & nd & nd & nd \\
\hline 662231 & 0.49 & nd & nd & nd & nd & nd & nd & nd & nd & nd & nd & nd \\
\hline 662232 & 19.57 & 0.36 & nd & 0.36 & nd & nd & nd & 0.04 & nd & nd & 0.04 & nd \\
\hline 662233 & 2.32 & nd & nd & nd & nd & nd & nd & nd & nd & nd & nd & nd \\
\hline 662234 & 7.12 & nd & nd & nd & nd & nd & nd & nd & nd & nd & nd & nd \\
\hline \multicolumn{13}{|c|}{ Trip Blanks } \\
\hline 662236 & nd & nd & nd & nd & nd & nd & nd & nd & nd & nd & nd & nd \\
\hline 662237 & bdl & nd & nd & nd & nd & nd & nd & nd & nd & nd & nd & nd \\
\hline 662238 & nd & nd & nd & nd & nd & nd & nd & nd & nd & nd & nd & nd \\
\hline
\end{tabular}


Table 4. Mass of volatile organic compounds detected in soil-gas samplers deployed on July 18, 2011, collected from the 12th Street site, Fort Gordon, Georgia.-Continued.

[MDL, method detection level; TPH, total petroleum hydrocarbons; $\mu \mathrm{g}$, micrograms; BTEX, benzene, toluene, ethylbenzene, and xylenes; ---, not applicable; $m$, meta; p, para; o, ortho; $\mathrm{C}_{11}, \mathrm{C}_{13}$, and $\mathrm{C}_{15}$, undecane, tridecane, and pentadecane; $c$, cis; $t$, trans; DCE, dichloroethylene; MTBE, methyl tert-butyl ether; DCA, dichloroethane; TCA, trichloroethane; TCE, trichloroethylene; PCE, perchloroethylene; DCB, dichlorobenzene; $\mathrm{CCl}_{4}$, carbon tetrachloride; nd, not detected; bdl, below detection level]

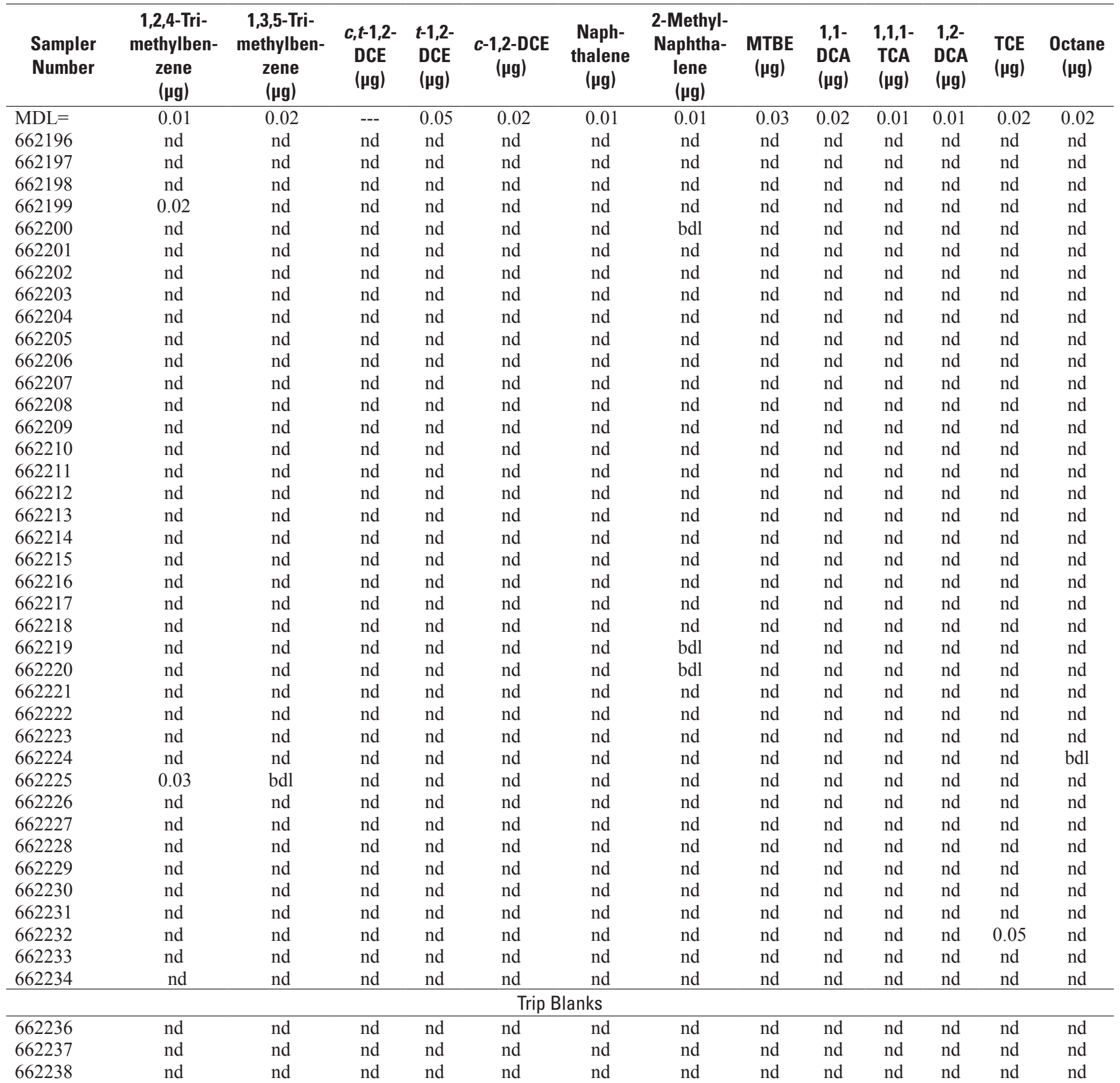


Table 4. Mass of volatile organic compounds detected in soil-gas samplers deployed on July18, 2011, collected from the 12th Street site, Fort Gordon, Georgia—Continued.

[MDL, method detection level; TPH, total petroleum hydrocarbons; $\mu \mathrm{g}$, micrograms; BTEX, benzene, toluene, ethylbenzene, and xylenes; ---, not applicable; $m$, meta; $p$, para; o, ortho; $\mathrm{C}_{11}, \mathrm{C}_{13}$, and $\mathrm{C}_{15}$, undecane, tridecane, and pentadecane; $c$, cis; $t$, trans; DCE, dichloroethylene; MTBE, methyl tert-butyl ether; DCA, dichloroethane; TCA, trichloroethane; TCE, trichloroethylene; PCE, perchloroethylene; DCB, dichlorobenzene; $\mathrm{CCl}_{4}$, carbon tetrachloride; nd, not detected; bdl, below detection level]

\begin{tabular}{|c|c|c|c|c|c|c|c|c|c|c|}
\hline $\begin{array}{l}\text { Sampler } \\
\text { Number }\end{array}$ & $\begin{array}{l}\text { PCE } \\
(\mu g)\end{array}$ & $\begin{array}{l}1-4- \\
\text { DCB } \\
(\mu g)\end{array}$ & $\begin{array}{c}\text { Chloro- } \\
\text { form } \\
(\mu g)\end{array}$ & $\begin{array}{l}\mathrm{CCI}_{4} \\
(\mu \mathrm{g})\end{array}$ & $\begin{array}{l}1,1,2- \\
\text { TCA } \\
(\mu g)\end{array}$ & $\begin{array}{l}\text { Chloro- } \\
\text { benzene } \\
(\mu \mathrm{g})\end{array}$ & $\begin{array}{c}\text { 1,1,1,2-Tetra- } \\
\text { chloroethane } \\
(\mu \mathrm{g})\end{array}$ & $\begin{array}{c}\text { 1,1,2,2-Tetra- } \\
\text { chloroethane } \\
(\mu \mathrm{g})\end{array}$ & $\begin{array}{c}\text { 1,3-Dichloro- } \\
\text { benzene } \\
(\mu \mathrm{g})\end{array}$ & $\begin{array}{l}\text { 1,2-Dichloro- } \\
\text { benzene } \\
(\mu \mathrm{g})\end{array}$ \\
\hline $\mathrm{MDL}=$ & 0.02 & 0.01 & 0.01 & 0.03 & 0.02 & 0.03 & 0.02 & 0.01 & 0.01 & 0.01 \\
\hline 662196 & nd & nd & nd & nd & nd & nd & nd & nd & nd & nd \\
\hline 662197 & nd & nd & nd & nd & nd & nd & nd & nd & nd & nd \\
\hline 662198 & nd & nd & 0.10 & nd & nd & nd & nd & nd & nd & nd \\
\hline 662199 & nd & nd & nd & nd & nd & nd & nd & nd & nd & nd \\
\hline 662200 & nd & nd & nd & nd & nd & nd & nd & nd & nd & nd \\
\hline 662201 & nd & nd & nd & nd & nd & nd & nd & nd & nd & nd \\
\hline 662202 & nd & nd & nd & nd & nd & nd & nd & nd & nd & nd \\
\hline 662203 & nd & nd & nd & nd & nd & nd & nd & nd & nd & nd \\
\hline 662204 & nd & nd & 0.10 & nd & nd & nd & nd & nd & nd & nd \\
\hline 662205 & bdl & nd & nd & nd & nd & nd & nd & nd & nd & nd \\
\hline 662206 & nd & nd & nd & nd & nd & nd & nd & nd & nd & nd \\
\hline 662207 & nd & nd & nd & nd & nd & nd & nd & nd & nd & nd \\
\hline 662208 & nd & nd & nd & nd & nd & nd & nd & nd & nd & nd \\
\hline 662209 & nd & nd & nd & nd & nd & nd & nd & nd & nd & nd \\
\hline 662210 & nd & nd & nd & nd & nd & nd & nd & nd & nd & nd \\
\hline 662211 & nd & nd & nd & nd & nd & nd & nd & nd & nd & nd \\
\hline 662212 & nd & nd & nd & nd & nd & nd & nd & nd & nd & nd \\
\hline 662213 & nd & nd & nd & nd & nd & nd & nd & nd & nd & nd \\
\hline 662214 & nd & nd & nd & nd & nd & nd & nd & nd & nd & nd \\
\hline 662215 & nd & nd & nd & nd & nd & nd & nd & nd & nd & nd \\
\hline 662216 & nd & nd & nd & nd & nd & nd & nd & nd & nd & nd \\
\hline 662217 & nd & nd & nd & nd & nd & nd & nd & nd & nd & nd \\
\hline 662218 & nd & nd & nd & nd & nd & nd & nd & nd & nd & nd \\
\hline 662219 & nd & nd & nd & nd & nd & nd & nd & nd & nd & nd \\
\hline 662220 & nd & nd & nd & nd & nd & nd & nd & nd & nd & nd \\
\hline 662221 & nd & nd & nd & nd & nd & nd & nd & nd & nd & nd \\
\hline 662222 & nd & nd & nd & nd & nd & nd & nd & nd & nd & nd \\
\hline 662223 & nd & nd & nd & nd & nd & nd & nd & nd & nd & nd \\
\hline 662224 & nd & nd & nd & nd & nd & nd & nd & nd & nd & nd \\
\hline 662225 & nd & nd & nd & nd & nd & nd & nd & nd & nd & nd \\
\hline 662226 & nd & nd & nd & nd & nd & nd & nd & nd & nd & nd \\
\hline 662227 & nd & nd & nd & nd & nd & nd & nd & nd & nd & nd \\
\hline 662228 & nd & nd & nd & nd & nd & nd & nd & nd & nd & nd \\
\hline 662229 & nd & nd & nd & nd & nd & nd & nd & nd & nd & nd \\
\hline 662230 & nd & nd & nd & nd & nd & nd & nd & nd & nd & nd \\
\hline 662231 & nd & nd & nd & nd & nd & nd & nd & nd & nd & nd \\
\hline 662232 & nd & 0.05 & nd & nd & nd & nd & nd & nd & nd & nd \\
\hline 662233 & nd & nd & nd & nd & nd & nd & nd & nd & nd & nd \\
\hline 662234 & nd & nd & 0.04 & nd & nd & nd & nd & nd & nd & nd \\
\hline \multicolumn{11}{|c|}{ Trip Blanks } \\
\hline 662236 & nd & nd & nd & nd & nd & nd & nd & nd & nd & nd \\
\hline 662237 & nd & nd & nd & nd & nd & nd & nd & nd & nd & nd \\
\hline 662238 & nd & nd & nd & nd & nd & nd & nd & nd & nd & nd \\
\hline
\end{tabular}





\section{Prepared by}

U.S. Geological Survey

Science Publishing Network

Raleigh Publishing Service Center

3916 Sunset Ridge Road

Raleigh, NC 27607

This publication is available only online at http://pubs.usgs.gov/of/2012/1082 
